\title{
WHY THE FIRST AMENDMENT CANNOT DICTATE COPYRIGHT POLICY
}

\author{
David McGowan
}

\section{INTRODUCTION}

For over thirty years scholars have suggested ways judges might use the First Amendment to limit Congress's power to grant authors exclusive rights in their works. ${ }^{1}$ The gist of most theories is that over the years Congress has increased the length and scope of authors' rights too much, crowding out the rights of users to consume expression and use it to create expression of their

\footnotetext{
* Associate Professor of Law and 2003-04 Julius E. Davis Professor of Law, University of Minnesota Law School (dmcgowan@umn.edu). Thanks to Brian Bix, Dan Farber, Dan Gifford, Mark Lemley, Miranda McGowan, Ruth Okediji, Maureen O'Rourke, Leo Raskind, and Tim Wu for their comments. Remaining mistakes are my fault.

1. Important works include C. Edwin Baker, Giving the Audience What it Wants, 58 Оніо ST. L.J. 311 (1997); Yochai Benkler, Free as the Air to Common Use: First Amendment Constraints on the Enclosure of the Public Domain, 74 N.Y.U. L. Rev. 354 (1999) [hereinafter Benkler, Free]; Yochai Benkler, Siren Songs and Amish Children: Autonomy, Information, and Law, 76 N.Y.U. L. REv. 23 (2001) [hereinafter Benkler, Siren];Yochai Benkler, Intellectual Property and the Organization of Information Production, 22 InT'L Rev. L. \& Econ. 81 (2002) [hereinafter Benkler, Information Production]; Yochai Benkler, Through the Looking Glass: Alice and the Constitutional Foundations of the Public Domain, 66 Law \& Contemp. Probs. 173 (2003) [hereinafter Benkler, Constitutional Foundations]; Robert C. Denicola, Copyright and Free Speech: Constitutional Limitations on the Protection of Expression, 67 Cal. L. Rev. 283 (1979); Paul Goldstein, Copyright and the First Amendment, 70 Colum. L. Rev. 983 (1970); Mark A. Lemley \& Eugene Volokh, Freedom of Speech and Injunctions in Intellectual Property Cases, 48 Duke L.J. 147 (1998); Lawrence Lessig, Copyright's First Amendment, 48 UCLA L. Rev. 1057 (2001); Neil Weinstock Netanel, Copyright and a Democratic Civil Society, 106 YaLE L.J. 283 (1996) [hereinafter Netanel, Civil Society]; Neil Weinstock Netanel, Locating Copyright Within the First Amendment Skein, 54 StAN. L. REV. 1 (2001) [hereinafterNetanel, Skein]; Neil Weinstock Netanel, Market Hierarchy and Copyright in our System of Free Expression, 53 VAND. L. REV. 1879 (2000) [hereinafter Netanel, Market Hierarchy]; Melville B. Nimmer, Does Copyright Abridge the First Amendment Guarantees of Free Speech and Press?, 17 UCLA L. Rev. 1180 (1970); L. Ray Patterson, Free Speech, Copyright, and Fair Use, 40 VAND. L. REv. 1 (1987); Jed Rubenfeld, The Freedom of Imagination: Copyright's Constitutionality, 112 YALE L.J. 1 (2002); Eugene Volokh, Freedom of Speech and Intellectual Property: Some Thoughts After Eldred, 44 Liquormart, Saderup, and Bartnicki, 40 Hous. L. Rev. 697 (2003); Alfred C. Yen, A First Amendment Perspective on the Idea/Expression Dichotomy and Copyright in a Work's "Total Concept and Feel," 38 EMORY L.J. 393 (1989). Though he did not write explicitly in First Amendment terms, Professor Chafee deserves credit for exploring the main arguments first. Zechariah Chafee, Jr., Reflections on the Law of Copyright: I, 45 Colum. L. Rev. 503 (1945).
} 
own. $^{2}$ The First Amendment, the argument goes, protects consumers and downstream speakers from copyright crowding-out.

Context is important to understanding why this argument is made. Many copyright scholars object to the way Congress deals with their subject. With good reason, they feel Congress wields a copyright ratchet: terms get longer, and the scope of rights gets wider, but never the reverse. ${ }^{3}$ (A rare exception occurred when publishers asked Congress to shore up fair use rights to make it easier for authors to get information they need to produce works. ${ }^{4}$ ) On this account, Congress is simply a tool rich media conglomerates use to soak consumers, who are rationally ignorant of the shameless fleecing their "representatives" give them.

It is no fun beating one's head against a wall. So if the representative branches sell out, at least by academic standards, the next best option is to limit their power to do harm. Two things are needed: a non-representative forum, to limit the power of producer wealth, and a law that trumps Congress's Article I power to grant exclusive rights to authors. ${ }^{5}$ The First Amendment seems like just the thing. Like copyright, it deals with expression, which makes almost any argument facially plausible. More importantly, in a conflict with Congress's Article I power, the First Amendment trumps. ${ }^{6}$

That is why the First Amendment argument is especially popular when Congress tinkers with copyright law. In 1970, as Congress was continuing the

2. See Goldstein, supra note 1, at 985 (noting "a gradual widening of authors' rights and a consequent diminution in the public's right to speak and to hear previously unprotected expressions"); Mark A. Lemley, The Constitutionalization of Technology Law, 15 BerkeLey TECH. L.J. 529, 531 (2000) (expansion of intellectual property rights strains the "uneasy truce" between such rights and the First Amendment); Diane Leenheer Zimmerman, Information as Speech, Information as Goods: Some Thoughts on Marketplaces and the Bill of Rights, 33 WM. \& MARY L. REv. 665, 667 (1992) ("[A]n ever-expanding array of new or reconstructed property theories is cannibalizing speech values at the margin.").

3. A history well summarized in Jessica Litman, Digital Copyright (2001). See also Benkler, Constitutional Foundations, supra note 1, at 196; Robert P. Merges, One Hundred Years of Solicitude: Intellectual Property Law, 1900-2000, 88 CAL. L. Rev. 2187 (2000).

4. See 17 U.S.C. $\$ 107$ (2000) ("“T]hat a work is unpublished shall not itself bar a finding of fair use if such finding is made upon consideration of' the fair use factors.).

5. U.S. ConsT. art. I, $\S 8$, cl. 8.

6. For example, one could not seriously maintain that Congress's Article I power would enable it to give Republican authors greater rights than Libertarian or Democratic authors. See Benkler, Constitutional Foundations, supra note 1, at 179. Such a viewpoint-biased copyright law is of course a fanciful example that has nothing in particular to do with real-world copyright. The same would be true of a law that allows courts to enjoin trespasses by Democrats but not Republicans. I mention it only to point out that the existence of an Article I power does not imply that laws passed under that power are immune from scrutiny under the Bill of Rights. 
debate that eventually produced the Copyright Act of $1976,{ }^{7}$ Professors Melville Nimmer and Paul Goldstein published important articles advancing relatively modest arguments about how copyright law and free speech could be reconciled. ${ }^{8}$ After the 1976 Act passed, interest in the topic quieted, except for a flurry surrounding the dispute over Gerald Ford's memoirs. ${ }^{9}$

Twenty-five years later, law and economics had made exclusive rights and contracting ("private ordering") more popular than it had been. Technology has a ratchet of its own-it continued to make copying cheaper and easier than ever, and the combination of digital content and networks such as the Internet enabled widespread, high-volume, high-quality copying. ${ }^{10}$ Large U.S. firms made ever-increasing amounts of money exporting copyrighted works to the rest of the world. ${ }^{11}$

Congress responded by giving authors exclusive rights for a longer time, ${ }^{12}$ and by prohibiting acts that threatened those rights. ${ }^{13}$ Scholars revived the free speech argument to fight back. Reconciling these bodies of law was not the target any more. Privatization of speech was out of hand and had to be stopped. Free speech arguments in this most recent round have been thoughtful and thought provoking. They have deserved and received wide attention in academic circles. ${ }^{14}$ Many copyright scholars agree with them. Courts do not.

Last term, in Eldred v. Ashcroft, the Supreme Court rejected a First Amendment challenge to Congress's decision to extend the copyright term for existing works. That was by far the most vulnerable provision in the new laws (there is a cogent utilitarian argument that it lacked even a rational basis), so

7. Copyright Act of 1976, Pub. L. No. 94-553, 90 Stat. 2541 (codified as amended at 17 U.S.C. $\S \S 101-810(2000))$.

8. Nimmer, supra note 1; Goldstein, supra note 1.

9. Harper \& Row, Publishers, Inc. v. Nation Enters., 471 U.S. 539 (1985). For reaction to the case, see, e.g., Stephen S. Morrill, Harper \& Row, Publishers v. Nation Enterprises: Emasculating the Fair Use Accommodation of Competing Copyright and First Amendment Interests, 79 Nw. U. L. REv. 587 (1984); David E. Shipley, Conflicts Between Copyright and the First Amendment After Harper \& Row, Publishers v. Nation Enterprises, 1986 B.Y.U. L. REv. 983 (1987).

10. Glynn S. Lunney, Jr., The Death of Copyright: Digital Technology, Private Copying, and the Digital Millennium Copyright Act, 87 VA. L. Rev. 813, 820 (2001).

11. H.R. ReP. No. 105-551, pt. I, at 10 (1998) (describing economic justification for the Digital Millennium Copyright Act).

12. Sonny Bono Copyright Term Extension Act, Pub. L. No. 105-298, § 102(b)(1), 112 Stat. 2827 (1998) (codified as amended at 17 U.S.C.).

13. Digital Millennium Copyright Act, Pub. L. No. 105-304, 112 Stat. 2860 (1998) (codified as amended in scattered sections of 17 U.S.C.).

14. Pam Samuelson, The Constitutional Law of Intellectual Property After Eldred v. Ashcroft, 50 J. COPYright Soc'y 547 (2003) (surveying the state of this literature). 
the Court's rejection is significant. The Court was not very clear on some aspects of the free speech issue. For example, Justice Ginsburg's majority opinion said the Copyright Act has "built-in" constitutional protections but did not give any hint of what the Constitution itself requires. ${ }^{15}$ The Court also said the First Amendment "bears less heavily" when the person who wants its protection is a copier rather than someone objecting to regulation of noninfringing speech. ${ }^{16}$ "Bears less heavily" may not be the clearest phrase, but it is clear enough that the Court thinks copiers are constitutional second-class citizens compared to non-infringing speakers. ${ }^{17}$

Courts also have rejected First Amendment challenges to Congress's power over the scope of an author's rights. The Digital Millennium Copyright Act ("DMCA") is most relevant here. It forbids persons from circumventing technical measures that limit access to copyrighted works and from trafficking in devices that circumvent such measures. ${ }^{18}$ The Second Circuit and a trial judge in the Northern District of California have rejected arguments that the DMCA violates the First Amendment by banning "speech" and by leaving users too little power to engage in what would otherwise be fair uses under the Copyright Act. ${ }^{19}$

There is no reason to expect this topic to go away, however. Congress will tinker with copyright again, which will prompt another round of such arguments. Many scholars and at least a couple of judges accept the idea that there has to be some limit to congressional power over copyright, and that the First Amendment is an attractive candidate to provide such a limit. It is therefore worth considering whether the First Amendment embodies values or principles a judge could actually use to limit Congress's power over copyright.

The answer to that question is no. The First Amendment does not supply a premise a court can use to limit congressional power to give authors rights to exclude others from their works, nor to give others-including other authors - the right to use their works. Congressional discretion is not absolute - nothing ever is — but it is so broad it is essentially pointless to talk

15. Eldred v. Ashcroft, 123 S. Ct. 769, 788 (2003).

16. Id. at 221 .

17. See In re Aimster Copyright Litig., 334 F.3d 643, 656 (7th Cir. 2003) (Posner, J.).

18. 17 U.S.C. $\S 1201(\mathrm{~b})(1)(2000)$.

19. Universal City Studios, Inc. v. Corley, 273 F.3d 429 (2d Cir. 2001); United States v. Elcom, Ltd., 203 F. Supp. 2d 1111 (N.D. Cal. 2002). For a more detailed analysis of the free speech aspect of these cases, see David McGowan, From Social Friction to Social Meaning: What Expressive Uses of Code Tell Us About Free Speech, 64 Oніо St. L.J. 1515 (2003). 
about a First Amendment right to any particular balance between authors and consumers, or between upstream and downstream authors.

When lower courts bring the First Amendment into copyright cases it is generally to give a rhetorical boost to a fair use analysis. ${ }^{20}$ Supreme Court references to the First Amendment in copyright are also rhetorical. Here the rhetoric is part of a dialogue in which the Court reminds Congress to keep an eye on both sides of a very general balancing analysis the Court is not competent to perform. As long as Congress does this, it has discretion to do what it wants.

There are three main reasons why the answer has to be no. First, the most plausible form of the copyright crowding-out argument pits an upstream author, such as Margaret Mitchell, against a downstream author, such as Alice Randall, who wishes to copy the initial author's work when creating a work of her own. ${ }^{21}$ The First Amendment deals with disputes between the state and authors, or between the targets of speech and authors. It does not provide premises for dealing with disputes between authors.

In part, this is because First Amendment doctrine takes a forward-looking perspective regarding incentives to produce expression. First Amendment doctrine does not take expression for granted. It asks whether laws such as libel will deter or "chill" expression by threatening to impose damages on speakers. ${ }^{22}$ Such laws cannot deter speech that already exists, of course, and First Amendment doctrines that deal with the risk of "chilling" speech take the perspective of a hypothetical speaker deciding whether to produce expression rather than the perspective of one who has already spoken. This forwardlooking perspective tends to collapse differences between upstream and downstream authors. In the relevant First Amendment doctrines, everyone is an upstream author.

Second, the free speech critique of copyright makes various empirical predictions that may be right, wrong, or completely backwards. The most common prediction is that giving upstream authors weak rights and downstream users broad rights will increase the "diversity" of expression. Once "diversity" is given substance, it is easy to see that using the First Amendment to guarantee minimum user rights could easily lessen diversity rather than increase it. Copying is cheaper than writing something yourself, so the more you can copy the more likely you are to copy, which is to say the

20. See, e.g., Suntrust Bank v. Houghton Mifflin Co., 268 F.3d 1257, 1264-65 (11th Cir. 2001).

21. Id. at 1259 .

22. See, e.g., Hustler Magazine, Inc. v. Falwell, 485 U.S. 46, 52 (1988); N.Y. Times Co. v. Sullivan, 376 U.S. 254, 277 (1964). 
more likely you are to recycle old content rather than create new content. The First Amendment offers no way to resolve this tangle of empirical predictions, nor any reason why Congress must bet one way or the other.

Third, free riding is not a First Amendment value. The Supreme Court in Eldred was right to imply that authors who do their own work advance some free speech values that copiers do not. Autonomy of speakers and diversity of expression are two such values. They are not the only First Amendment values, of course, but they are important. Giving upstream authors strong rights, which is what we do now, gives downstream users an incentive to do more of their own work than they would have to do if they could copy at will. Congress is not required to adopt laws that give people incentives to do their own work rather than copying others, but the First Amendment certainly does not prohibit it from doing so.

One strand of the crowding-out argument holds that free riding is justified as a way to ensure that speakers have an equal voice. For any given type of work, however, copyright law gives all speakers the same rights. Authors may sell or combine these rights in ways that make some works, or types of works, more popular than others. It is true that formal equality of rights is unlikely to give all speakers an equal voice, but the First Amendment does not require that speakers have an equal voice. In fact, it is more consistent with First Amendment doctrine and values to say that government has no power to decide that some voices are too loud and others too soft, much less to try to limit the rights of some speakers to enhance the power of others.

Part I of this article surveys the reasons copyright critics have given for the proposition that the First Amendment can and should limit the length and scope of copyright. Part II discusses doctrinal reasons why that proposition should be rejected. Part III discusses normative reasons why the proposition should be rejected. Part IV discusses how we should read the Court's recurrent comment that the Copyright Act has "built-in" constitutional protections.

\section{The Copyright Crowding-Out Critique}

The copyright crowding-out argument dates to 1970 . In that year, Professors Melville Nimmer and Paul Goldstein wrote well-known articles advancing different versions of the argument. Professor Nimmer tried to reconcile copyright and free speech through the "definitional balancing" technique he thought the Supreme Court adopted in New York Times v. 
Sullivan. ${ }^{23}$ He focused on aspects of the balance between copyright and free speech he thought were right ${ }^{24}$ or wrong. The rule that expression may be copyrighted, but not the ideas expressed, was right, for example, while Congress's plan (as it was in 1970) to extend the copyright term for existing works was wrong. ${ }^{25}$

Professor Nimmer thought some expression could not be separated from its idea and was too important to risk being "censored" by the rights-holder. He gave as examples news photographs of important events, such as Ronald Haeberle's photographs of soldiers killing civilians at My Lai, ${ }^{26}$ and Abraham Zapruder's film of President Kennedy being shot. ${ }^{27}$ He favored a compulsory license approach to such expression. He had no sympathy for those who copied expression when they could have created their own, however, saying "[o]ne who pirates the expression of another is not engaging in self-expression in any meaningful sense." ${ }^{28}$

Professor Goldstein worried both about the scope of copyright and the accumulation of rights by large media firms, which he called "enterprise monopolies." ${ }^{29}$ To illustrate the risks of both, he cited Rosemount Enterprises, Inc. v. Random House, Inc., ${ }^{30}$ in which Howard Hughes tried to use copyright to suppress an unauthorized biography. The book's author had copied from some magazine articles. A company Hughes controlled bought the rights to the articles and sued for infringement. The Second Circuit reversed a preliminary injunction against publication, saying the plaintiff had not shown a strong infringement claim while the defendants had a strong fair use defense. $^{31}$

Professor Goldstein thought Rosemount was a clear case of copyright being used to censor rather than promote expression, and that the court got it right. $^{32}$ In contrast, Professor Nimmer criticized the Second Circuit because the author had free use of the unprotected facts and ideas regarding Hughes's

23. 376 U.S. 254 (1964).

24. Nimmer, supra note 1, at 1189 (idea/expression), 1193 (extension).

25. Id. at 1194-95.

26. Id. at 1197-98; see http://www.law/umkc.edu/faculty/projects/ftrials/mylai/MYL_PHO.HTM (last visited Dec. 5, 2003).

27. Nimmer, supra note 1, at 1198; see Time Inc. v. Bernard Geis Assoc., 293 F. Supp. 130 (S.D.N.Y. 1968).

28. Nimmer, supra note 1, at 1192.

29. Goldstein, supra note 1, at 987.

30. Rosemont Enters., Inc. v. Random House Inc., 366 F.2d 303 (2d Cir. 1966).

31. Id. at 306-07.

32. Goldstein, supra note 1, at 985-86. 
life and did not have to copy the articles to write his book. ${ }^{33}$ As we have seen, Professor Nimmer had little sympathy for a First Amendment right to copy. ${ }^{34}$

To reconcile conflicts between copyright and free speech, Professor Goldstein proposed that: (i) infringement be excused if what was copied was "relevant to the public interest" and the copier's use "independently advance[d] the public interest"; (ii) only "original" works be protected; and (iii) courts award damages rather than injunctions as the default remedy for infringement. ${ }^{35}$ As noted above, Professor Nimmer worried about injunctions in some cases, too. ${ }^{36}$ Understandably, for the time in which they wrote, neither author discussed the difference between damages and injunctions in terms of the relative efficiency of property rules and liability rules. ${ }^{37}$

Professors Goldstein and Nimmer each thought New York Times v. Sullivan ${ }^{38}$ said something important about the relationship between copyright and free speech. As I noted a moment ago, Nimmer worked within the "definitional balancing" approach he thought Sullivan represented. ${ }^{39}$ Goldstein read Sullivan as holding that laws which "clog the dissemination of matter in the public interest are illegitimate." ${ }^{\text {"No }}$ Sullivan is still a favorite of those who would use the First Amendment to limit Congress's power over copyright. ${ }^{41}$

After Nimmer and Goldstein laid the groundwork, Congress passed the Copyright Act of 1976, and interest in the First Amendment as a restraint on copyright dropped off a bit. An article assessing the lay of the land after the 1976 Act became law continued Nimmer's general line of analysis, ${ }^{42}$ and some scholars used First Amendment arguments to criticize Harper \& Row

33. Nimmer, supra note 1, at 1202-03.

34. Id.

35. Goldstein, supra note 1, at 988.

36. See Nimmer, supra note 1, at 1199-1200.

37. The foundational article in this literature appeared two years later. See Guido Calabresi \& A. Douglas Melamed, Property Rules, Liability Rules, and Inalienability: One View of the Cathedral, 85 HARV. L. REV. 1089, 1092 (1972) (“An entitlement is protected by a property rule to the extent that someone who wishes to remove the entitlement from its holder must buy it from him in a voluntary transaction in which the value of the entitlement is agreed upon by the seller.").

38. 376 U.S. 254 (1964).

39. Nimmer, supra note 1, at 1186-88. A view he discussed more fully in Melville B. Nimmer, The Right to Speak from Times to Time: First Amendment Theory Applied to Libel and Misapplied to Privacy, 56 CAL. L. REv. 935, 942 (1968).

40. Goldstein, supra note 1, at 995 . This reading fails to capture the economics of the case. See infra Part IIA.

41. See Benkler, Free, supra note 1, at 365; Rubenfeld, supra note 1, at 26-27.

42. Denicola, supra note 1. 
Publishers, Inc. v. Nation Enterprises ${ }^{43}$ but there was little systematic exploration of the topic.

That changed in the mid-1990s, when Congress again turned its attention to copyright. ${ }^{44}$ Many scholars contributed to this discussion, and I cannot do justice here to all the arguments they raised. A survey of the main points will have to do. In a series of articles, Professor Neil Weinstock Netanel argued that copyright law is harming "democratic civil society" by giving rightsholders too much power, and users too little, thus encroaching on First Amendment rights. ${ }^{45}$ Like Professor Nimmer before him, Professor Netanel targeted Congress's decision to extend the copyright term for existing works. ${ }^{46}$ He also criticized the DMCA, digital rights management, and private ordering more generally, including price discrimination and contractual terms that keep users from doing things the Copyright Act would let them do. ${ }^{47}$

Professor Netanel added two important arguments to the copyright crowding-out argument. The first I will call the "passivity thesis." It turns on authoritarian relations, which Professor Netanel defines as those in which one person exercises power over another. ${ }^{48}$ Authoritarian relations are bad because they "may foster deference and servility rather than the culture of assertive autonomy upon which democracy rests." ${ }^{49}$ Copyright may free authors from some authoritarian relations, such as dependence on government grants or rich patrons. But if Congress gives authors too much power, rightsholders may oppress downstream users, placing them in a subservient role. ${ }^{50}$ Professor Benkler has advanced a related idea, holding that there is an inverse relation between privatization of expression and the degree to which citizens engage in democratic processes. ${ }^{51}$

The second argument is that if rights-holders have too much power public discourse will not be as "robust" as it should be. Professor Netanel

43. 471 U.S. 539 (1985). For the commentary, see sources cited supra note 9.

44. Netanel, Civil Society, supra note 1, at 285-86 ("[A]n extraordinarily bitter battle is raging in Congress, the courts, law reviews, Internet discussion groups, and numerous international fora over the purpose and scope of copyright as we enter the digital age.").

45. Id. at 341-42; Netanel, Skein, supra note 1, at 4-5. Professor Netanel defined "democratic civil society as a "sphere of voluntary, nongovernmental association in which individuals determine their shared purposes and norms." Netanel, Civil Society, supra note 1, at 342.

46. Netanel, Civil Society, supra note 1, at 298-99; 366-67.

47. Netanel, Skein, supra note 1, at 23-24.

48. See Netanel, Civil Society, supra note 1, at 345. $379-83$.

49. Id. Professor Benkler articulates a variation on this thesis. Benkler, Free, supra note 1, at

50. Netanel, Civil Society, supra note 1, at 362-63.

51. Benkler, Constitutional Foundations, supra note 1, at 187. 
acknowledges that copyright provides a way of matching production of works with demand, but he fears an excessively privatized, demand-driven system would produce excessively homogenous expression. ${ }^{52}$ He worries that rightsholders might charge too much for licenses to create derivative works, if they would license at all, transaction costs might prevent licensing even where both sides were willing to do a deal, and cognitive biases might lead both producers and users to under-value unusual expression. ${ }^{53}$ Demand is therefore not a good measure of social value of expression. ${ }^{54}$ With markets in expression doing such a bad job, Professor Netanel argued the government might need to regulate expression, through subsidy or otherwise, to create more robust public debate. ${ }^{55}$ I will call this the "robustness thesis."

It is hard to analyze the "robustness" of public discourse. Is a debate over science textbooks more robust if $90 \%$ of the content is produced by evolution advocates or if the content is split fifty-fifty with evangelical Christians? Does the same go for histories of the Nazi regime? Is there a robust debate over who shot President Kennedy, or is it just a crackpot's ball? Is there a difference? Are 100 variations on Gone With the Wind more robust than ten original novels of slavery or chivalry in the South?

In later work, however, Professor Netanel defines the term more precisely. He identifies a "Free Speech Principle," which includes the proposition that robust public debate must include contributions from "diverse and antagonistic sources." " 56 Professor Benkler has advanced a similar thesis, arguing "the First Amendment requires a robust public domain" and therefore limits how far government may recognize private rights in information. ${ }^{57}$ As authority for this idea, Professors Netanel and Benkler both cite Justice Black's comment in Associated Press v. United States ${ }^{58}$ that the First Amendment values both "the widest possible dissemination of information" and the dissemination of such information from "diverse and antagonistic sources." ${ }^{59}$

52. Netanel, Civil Society, supra note 1, at 333-36.

53. Id.

54. Id. at 339 n.271. Professor Netanel defends this proposition on the alternative grounds that information is a public good, and therefore demand understates its value, or that the contribution of information to society is an "irreducibly social good," in which case demand cannot state its value. Id. For an extensive critique of markets in expression, see Baker, supra note 1.

55. Netanel, Civil Society, supra note 1, at 359.

56. Netanel, Market Hierarchy, supra note 1, at 1881.

57. Benkler, Free, supra note 1, at 358.

58. Associated Press v. United States, 326 U.S. 1 (1945).

59. Id. at 20 . 
The passivity and robustness arguments are interesting in their own right, but they need a doctrinal hook similar to Professor Nimmer's suggestion that "definitional balancing" be extended to copyright. Professor Netanel suggests that courts treat the Copyright Act as a content-neutral regulation of speech and subject it to "intermediate scrutiny." Such regulations are reviewed to determine whether they advance a substantial governmental interest and do not "burden substantially more speech than is necessary to further the government's legitimate interests." 60

Finally, Professor Jed Rubenfeld argues that the First Amendment limits copyright by protecting an absolute freedom of imagination, so that "no one can be penalized for imagining or for communicating what he imagines. Nor can a person be required to obtain permission from anyone in order to exercise his imagination." ${ }^{61}$ The prohibition on literal copying found in the reproduction right does not encroach on this freedom, but copyright's grant to authors of the right to make derivative works and to control the performance of a work does.

These arguments reflect the thoughtful engagement of brilliant scholars committed to an admirable vision of the public interest. Nevertheless, in what follows I contend that none of these arguments makes a persuasive case for using the First Amendment to limit, in any significant respect, Congress's power over copyright. I will begin with doctrinal considerations.

\section{Why Levels of Scrutiny Cannot Dictate Copyright Policy}

Most free speech critiques of copyright take it for granted that copyright is a governmental restriction on speech. For most of this article I will also work under that assumption, but it is useful to start by noting that this characterization obscures two important points. First, copyright gives power to rights-holders, not the government. No one forces an author to claim copyright rather than place a work in the public domain. No one forces an author to assert her rights. A rights-holder may authorize copying and thereby make it legal, which is not something a private citizen can do with regard to unprotected speech, such as obscenity.

This difference is important. Private parties probably maximize income or a vision of artistic integrity most of the time - more often, at least, than they maximize the sort of political ends that preoccupy government officials. To

60. Turner Broad. Sys. Inc. v. FCC, 512 U.S. 622, 662 (1994).

61. Rubenfeld, supra note 1, at 4. 
the extent this conjecture is correct, laws granting exclusive rights to private authors imply less politically motivated suppression than governmental prohibitions imply.

Nevertheless, the crowding-out argument does its best to cast copyright as a tool of political suppression. All of its advocates stress cases with obvious political overtones, not garden-variety infringement suits. ${ }^{62}$ Unless one assumes most copyrighted works are like the Zapruder film, the My Lai photographs, or a translation of Mein Kampf, and most authors are like Hitler or the Church of Scientology, however, these examples present a skewed picture of the law as a whole. One can protest that a private party owns a famous painting, but that example hardly suggests that society is impoverished by being excluded from seeing what hangs on most people's walls.

Second, not all copyrighted works are First Amendment "speech." Whether acts or objects related to expression amount to "speech" depends on many things, notably the work itself, the context in which it is presented, and the social practices and understandings relevant to both text and context. ${ }^{63}$ Copyright grants exclusive rights in many things that, in their most common use, advance values other than the First Amendment values of deliberation and debate, and therefore would not be treated as First Amendment "speech." Architectural drawings, ${ }^{64}$ conventionally distributed computer software, ${ }^{65}$ forms that convey information, ${ }^{66}$ and taxonomies of dental procedures ${ }^{67}$ exemplify the point. ${ }^{68}$ Because not all copyrighted works are First Amendment "speech," while all works get the same nominal statutory protection, ${ }^{69}$ characterizing copyright as a regulation of speech makes the statute seem more targeted at "speech" than it really is.

62. E.g. Netanel, Skein, supra note 1, at 14 (listing as examples of authors several who appear motivated by things other than money, including Adolf Hitler, two churches, the Minneapolis police department, and J.D. Salinger); Nimmer, supra note 1, at 1199 (mentioning Zapruder film and photographs of My Lai massacre).

63. See McGowan, supra note 19. 1994).

64. 17 U.S.C. $\$ 101$ (2000); Fred Riley Home Bldg. Corp. v. Cosgrove, 864 F. Supp. 1034 (D. Kan.

65. Commodities Futures Trading Comm'n v. Vartuli, 228 F.3d 94 (2d Cir. 2000).

66. Bibbero Sys., Inc. v. Colwell Sys., Inc., 893 F.2d 1104 (9th Cir. 1990).

67. Am. Dental Ass'n v. Delta Dental Plans Ass'n, 126 F.3d 977 (7th Cir. 1997) (Easterbrook, J.).

68. Such things may be used in contexts that render them protected speech, of course, as may virtually anything. And depending on the facts of particular cases, flat prohibitions of some such works might run afoul of the First Amendment. None of these things would be subject to special liability rules if they led to harm when used in their most conventional way, however.

69. One exception here is the "thin" copyright that is said to extend to some works, such as compilations. See Feist Publ'ns, Inc. v. Rural Tel. Serv. Co., 499 U.S. 340 (1991). 
With these qualifications in mind, we can explore how the copyright crowding-out argument tries to fit copyright into the Court's First Amendment architecture. Since Police Department of Chicago v. Mosley ${ }^{70}$ the Court has discussed First Amendment cases using a multi-tiered approach borrowed from equal protection analysis. The key doctrinal inquiry is whether "the government has adopted a regulation of speech because of [agreement or] disagreement with the message it conveys." "71 "[L]aws that by their terms distinguish favored speech from disfavored speech on the basis of the ideas or views expressed are content based." " Such laws face "the most exacting" scrutiny. ${ }^{73}$ Laws that "confer benefits or impose burdens on speech without reference to the ideas or views expressed are in most instances content neutral." "74 They face "an intermediate level of scrutiny because in most cases they pose a less substantial risk of excising certain ideas or viewpoints from the public dialogue." ${ }^{75}$

The categorical rhetoric this approach employs fits poorly with the values and facts that decide actual cases. ${ }^{76}$ The Court is concerned with the state of "public discourse." Categories help it evaluate the relation of a law to that discourse; they are not ends in themselves. ${ }^{77}$ Thus, facially neutral laws may be treated as content-based because their purpose is content-based. ${ }^{78}$ Laws that appear content-based may be analyzed as content-neutral ${ }^{79}$ or justified on some other ground. ${ }^{80}$ In almost all the cases, obviously content-based regulations of perjury, price-fixing, blackmail, and extortion quite properlyget no First Amendment scrutiny at all, ${ }^{81}$ though the Court's categorical rhetoric

70. Police Dep't of Chicago v. Mosley, 408 U.S. 92 (1972).

71. Turner Broad. Sys., Inc. v. FCC, 512 U.S. 622, 642 (1994) (quoting Ward v. Rock Against Racism, 419 U.S. 781, 791 (1989)).

72. Id. at 643 .

73. Id. at 642 .

74. Id. at 643 .

75. Id. at 642 .

76. E.g. Robert Post, Recuperating First Amendment Doctrine, 47 Stan. L. Rev. 1249 (1995) (arguing that the Court's First Amendment language does not accurately express the values its decisions embody).

77. The term the Court has used to describe First Amendment interaction. See Cohen v. California, 403 U.S. 15, 22 (1971); Hustler Magazine, Inc. v. Falwell, 485 U.S. 46, 55 (1988).

78. United States v. Eichman, 496 U.S. 310, 315 (1991).

79. City of Ladue v. Gilleo, 512 U.S. 43, 55 (1994).

80. City of Erie v. Pap's A.M., 529 U.S. 277, 279 (2000); Renton v. Playtime Theatres, Inc., 475 U.S. 41, 47-48 (1986).

81. Hill v. Colorado, 530 U.S. 703, 721 (2000). 
cannot explain why that should be. To explain such results courts have to rely in part on content. ${ }^{82}$

Professor Netanel analyzes copyright as a content-neutral regulation of speech. ${ }^{83}$ Professor Benkler largely agrees. ${ }^{84}$ Professor Rubenfeld agrees with regard to the reproduction right but not the derivative right. ${ }^{85}$ I believe Professor Netanel is right, and I will discuss his argument in a moment. First, however, I will address the argument that copyright should be treated as a content-based regulation. Professor Eugene Volokh argues that copyright is content-based because the prohibition of the reproduction right does not apply unless "the content of the speech is substantially similar to the content of already-produced speech . . .." ${ }^{\prime 86} \mathrm{He}$ also argues the fair use exception is content-based because it inquires into the "purpose and character" of a downstream work. ${ }^{87}$ Professor Rubenfeld makes a similar point. ${ }^{88}$

If the First Amendment demands heightened scrutiny of any law that refers to the content of expression, then copyright would indeed be subject to heightened scrutiny. That is not what the First Amendment does, however. As the examples of blackmail and price-fixing suggest, there is nothing inherently suspicious about content-based distinctions. ${ }^{89}$ Indeed, it would be impossible to ascertain the boundaries of free speech without analyzing content; it is therefore impossible to do First Amendment law without analyzing content.

The distinction between content-based and content-neutral regulations is simply a tool to help courts identify situations in which First Amendment values should trump competing values. It has no other significance. Whether to use this particular tool is a choice that is expressed by classifying a rule as content-based or content-neutral. That means the classification in turn is a

82. See United States v. Barnett, 667 F.2d 835 (9th Cir. 1982) (holding that the First Amendment is no defense against aiding and abetting indictment based on mail-order sale of instructions on manufacturing drugs); United States v. Freeman, 761 F.2d 549 (9th Cir. 1982) (discussing circumstances in which the First Amendment would and would not provide a defense against indictment for aiding and abetting violations of tax laws); United States v. Buttorff, 572 F.2d 619 (8th Cir. 1978) (rejecting First Amendment defense to indictment for aiding and abetting violation of tax laws).

83. Netanel, Skein, supra note 1 , at 6.

84. Benkler, Constitutional Foundations, supra note 1, at 178. Professor Benkler believes certain provisions, such as the anti-device provisions of the DMCA, are best analyzed as content-based restrictions. Id.

\footnotetext{
85. Rubenfeld, supra note 1 , at 49.

86. Volokh, supra note 1 , at 702.

87. Id. at 705-06 (quoting 17 U.S.C. § 107(1) (2000)).

88. Rubenfeld, supra note 1 , at 48.

89. Hill v. Colorado, 530 U.S. 703, 721 (2000).
} 
choice, not a conclusion compelled by abstract textual analysis. The choice can only be made with reference to text, context, and the relation of those variables to First Amendment values. It is the relationship between the restriction and the values that drives the classification, not the other way around.

The reproduction right does not present the risk of harm to free speech values that heightened scrutiny is designed to guard against. The right calls for one text to be compared to another, regardless of the subject or viewpoint of either text. It does not call for a text to be compared to the government's view of acceptable speech. The reproduction right therefore does not create the risk of governmental favoritism or manipulation of dialogue, which the First Amendment guards against. Because the right does not threaten the values expressed in the distinction between content-based and content-neutral laws, ${ }^{90}$ that distinction does not help evaluate the right.

It is true that the fair use defense to infringement implies deeper judicial evaluation of speech than does the reproduction right. This fact does not mean heightened scrutiny is the right tool to analyze cases presenting this defense, however. To begin with, it shows a flaw in applying equal protection methods to expression. One could cure the problem by eliminating the defense, though the Court has said fair use plays an important role in balancing the interests of upstream and downstream speakers, which suggests discrimination is at best only part of what is at stake here. ${ }^{91}$ If and to the extent one believes the fair use doctrine itself has some constitutional dimension to it, it makes no sense to use it to justify reviewing copyright as a whole under heightened scrutiny, which is presumably triggered by things that threaten rather than embody constitutional values.

More fundamentally, the purpose of the fair use defense is to tailor rights to particular situations, with an emphasis on the economic effects of particular uses. ${ }^{92}$ The analysis is designed to produce a more tailored balance between speakers, or between producers and consumers, than the statute alone can provide. First Amendment values are on both sides of each of these equations. Because First Amendment interests are on both sides, each party could claim

90. See Turner Broad. Sys., Inc. v. FCC, 512 U.S. 622, 641-43 (1994). In the Court's language, the reproduction right does not "by [its] terms distinguish favored speech from disfavored speech on the basis of the ideas or views expressed ...." Id. at 643. The right therefore does not present a risk "of excising certain ideas or viewpoints from the public dialogue." Id. at 642 (emphasis added).

91. See infra Part IV.

92. Campbell v. Acuff-Rose Music, Inc., 510 U.S. 569, 574 (1994) (explaining that economic effects are the most significant element of fair use analysis). 
the benefit of heightened scrutiny. ${ }^{93}$ That means heightened scrutiny is not going to provide an answer to these cases.

It is tempting to respond to this by saying the First Amendment forbids government officials such as judges from trying to equilibrate speech interests. Within its domain, the argument would go, the First Amendment demands that speech trumps. This proposition makes sense, and heightened scrutiny works well enough, when a court deals with regulations that favor particular types of speech, or that limit speech to advance competing non-speech goals, such as public order ${ }^{94}$ reputation, ${ }^{95}$ civility, ${ }^{96}$ or keeping the money supply safe from counterfeiting. ${ }^{97}$ Neither risk is present with regard to either the reproduction right or the fair use defense, however. For these reasons, heightened scrutiny is not the right tool to analyze copyright law, and there is no reason to treat copyright as a content-based statute.

Analyzing copyright as content-neutral makes more sense. This analysis ultimately does not support the copyright crowding-out argument, however. To the extent the labels "content-neutral regulation of speech" and "intermediate scrutiny" suggest anything, it is that when courts apply them, the government wins. ${ }^{98}$ Professor Netanel is aware of this, ${ }^{99}$ so he argues that copyright should be evaluated under a particularly strict flavor of intermediate scrutiny, exemplified by Turner Broadcasting Sys., Inc. v. FCC. ${ }^{100}$ This was the plaintiffs' First Amendment theory in Eldred v. Ashcroft, and Professor Larry Lessig (whose case it was) therefore deserves credit for the argument as well. ${ }^{101}$

93. See infra Part IIIA.

94. Brandenburg v. Ohio, 395 U.S. 444, 447 (1969).

95. N.Y. Times Co. v. Sullivan, 376 U.S. 254, 267 (1964).

96. Hustler Magazine, Inc. v. Falwell, 485 U.S. 46, 55 (1988).

97. Regan v. Time, Inc., 468 U.S. 641, 648 (1984).

98. E.g. Ward v. Rock Against Racism, 491 U.S. 781 (1989); Members of City Council v. Taxpayers for Vincent, 466 U.S. 789 (1984) (affirming ban on posting messages on utility poles); United States v. O'Brien, 391 U.S. 367 (1968) (affirming conviction for burning of draft card at anti-war rally); Daniel A. Farber, The First Amendment 26 (1998) (noting that "the most typical aspect of the decisions" in this line of cases is that "they uphold the government regulation"); Larry A. Alexander, Trouble on Track Two: Incidental Regulations of Speech and Free Speech Theory, 44 HASTINGS L.J. 921 (1993).

99. Netanel, Skein, supra note 1 , at 6 .

100. 512 U.S. 622 (1994). For more on the differences between Turner-style intermediate scrutiny and other applications of that term, see Nancy J. Whitmore, The Evolution of Intermediate Scrutiny Standards and the Rise of the Bottleneck "Rule" in the Turner Decisions, 8 Comm. L. \& PoL'y 25 (2003).

101. Professor Netanel recognized the argument that the Court's free speech rhetoric and categories fit poorly with the values and contextual facts that decide actual cases. Netanel, Skein, supra note 1, at 32 . He worked within those categories, however, because he did not see the Court giving them up. Id. He is 
The facts of Turner have little to do with copyright. The law at issue required cable television firms to devote some bandwidth to carrying local broadcast programming. Noting that "the physical connection between the television set and the cable network gives the cable operator bottleneck, or gatekeeper, control" ${ }^{\prime 102}$ over programming, the Court viewed the regulations charitably as designed to protect broadcasters from "unfair competition" by cable firms, rather than to favor one type of speech over others. ${ }^{103}$

One can debate whether Congress was right to say cable firms competed unfairly with broadcasters, ${ }^{104}$ but the Court treated the regulations in Turner as compelling open access to a natural monopoly facility. Governments may compel access to such facilities because, if the facility really is a natural monopoly, it is socially wasteful to build competing facilities. ${ }^{105}$ That is not the case with copyright. Authors can generally do their own work rather than copy. It may or may not be the best policy for the law to give authors incentives to do their own work, but such a policy is not socially wasteful in the sense that duplicating natural monopoly facilities is. No one should have been surprised when the Eldred Court distinguished Turner on factual grounds, saying it "bears little on copyright."106

Moreover, even if one considers Turner as presenting a conflict between two free speech interests, as Justice Breyer did,${ }^{107}$ the decision implies that Congress has substantial discretion to balance those interests when tinkering with speech-related rights to exclude. Nothing in Turner suggests the First Amendment compelled the must-carry rule. There is a good reason for that. It is hard enough for a court to decide "whether the legislative conclusion was reasonable and supported by substantial evidence in the record before Congress." ${ }^{108}$ It would be too hard for a court to choose which rule, among a set of possible property rules, the First Amendment requires, especially

right about that, but the fact remains that categorical language such as the Court used in Turner means very little when divorced from the facts of particular cases.

102. 512 U.S. at 656. The Court reinforced its emphasis on the "bottleneck" idea by saying the First Amendment does not prevent Congress from limiting strategic behavior that might arise from "physical control of a critical pathway of communication." Id. at 657 (emphasis added). The bottleneck emphasis reconciled Turner with Miami Herald Pub. Co. v. Tornillo, 418 U.S. 241 (1974), which held the First Amendment creates no right of access to newspapers.

103. 512 U.S. at 652.

104. Whitmore, supra note 100, at 61-62.

105. Richard A. Posner, Natural Monopoly and Its Regulation, 21 StAn. L. Rev. 548 (1969).

106. Eldred v. Ashcroft, 123 S. Ct. 769,789 (2003).

107. Turner Broad. Sys., Inc. v. FCC, 520 U.S. 180, 226-27 (1997) (Breyer, J., concurring).

108. Id. at 211 . 
because the First Amendment itself offers no premise for making the choice. Any such decision would look and be essentially arbitrary.

The Turner argument is really more about the burden of proof than about free speech values as such. If the Copyright Act is treated as a content-neutral regulation of speech, the government bears the burden of showing the Act does not burden more speech than necessary to achieve its goals. ${ }^{109}$ No one knows the marginal effects of different possible copyright rules, however, ${ }^{110}$ so Congress probably could not have shown that extending the term did not burden more speech than was necessary to obtain whatever benefits Congress sought. The Eldred plaintiffs could not show the opposite. ${ }^{11}$

The burden shift strategy goes too far to be a persuasive free speech argument, however. Congress might not be able to show that any copyright term met the Turner standard. The rights to most reports of topical news are probably worthless within months after the reports are published. The rights in a lot of software and music are probably worthless within ten or fifteen years. If we take burden-shifting seriously, the strategy might well invalidate copyright as a whole, a point the Court grasped instantly in rejecting the plaintiffs' claim that marginal returns to the Copyright Term Extension Act were too low to justify the Act under Congress's Article I power. ${ }^{112}$

One could of course argue that copyright is unconstitutional top to bottom, and the Court was wrong not to say so. There is a logically valid argument that the First Amendment invalidates copyright altogether. ${ }^{113}$ At any practical level, however, under virtually every jurisprudential theory, the argument is unsound. No one who advances the copyright crowding-out argument is willing to go that far. ${ }^{114}$ If one is not willing to go that far, however, then citing Turner does nothing to identify a stopping point in the unraveling the burden-shifting strategy would start. The Court might read the

109. Benkler, Constitutional Foundations, supra note 1, at 178-79.

110. Frank H. Easterbrook, Cyberspace vs. Property Law?, 4 Tex. Rev. L. \& Pol. 103, 105 (1999); Frank H. Easterbrook, Cyberspace and the Law of the Horse, 1996 U. CHI. LEgAL F. 207 (same) [hereinafter Easterbrook, Law of the Horse].

111. I happen to think the plaintiffs' economic analysis was correct as far as it goes, but it rested on basic principles of financial economics, not data, and predicted trivial positive returns, not the absence of such returns. See Brief in Support of Petitioners, Eldred v. Ashcroft, 123 S. Ct. 769 (2003) (No. 01-618), available at http://cyber.law.harvard.edu/openlaw/eldredvashcroft/supct/amici/economists.pdf(last visited Dec. 5, 2003). For an argument that the analysis did not go far enough, see Stan J. Liebowitz \& Stephen E. Margolis, Seventeen Famous Economists Weigh in on Copyright: The Role of Theory, Empirics, and Network Effects (2003), at http://ssrn.com/abstract=488085 (last visited Feb. 20, 2004).

112. Eldred v. Ashcroft, 123 S. Ct. 769, 782 n.15, 784 n.16 (2003).

113. See Nimmer, supra note 1, at 1181; Benkler, Free, supra note 1, at 393.

114. Netanel, Skein, supra note 1, at 38. 
First Amendment as requiring it to ask whether Congress acted on "substantial" evidence, but there is no sense in pretending the First Amendment tells the Court what "substantial" means.

At this point it is useful to recall the two qualifications with which we started. Copyright gives power to rights-holders, not the government, and it protects things that do not receive First Amendment protection. These facts make copyright look much less like a law targeted at speech, much less at content or viewpoints, and much more like other laws that affect significant amounts of expression, even though they are not explicitly targeted at expression. ${ }^{115}$

As Professor Larry Alexander has pointed out, "all laws have information effects," and therefore can be classified as content-neutral regulations of speech. ${ }^{116}$ If marginal tax rates were lower, one could produce or consume more expression; if fire codes weren't so restrictive, more people could attend lectures or concerts; if battery were legal, new avenues of symbolic expression would be open, and so on. That is why, as I mentioned earlier, courts have been extremely deferential to government regulations challenged as contentneutral regulations of speech. Any other approach would threaten virtually all laws. If copyright has no greater First Amendment claim than real property laws or laws against theft, it has no claim at all.

Against this, it might be said that even if some copyrighted material is not "speech," quite a lot of it is, and unlike marginal tax rates or battery laws, copyright attaches to expression as such. The relationship between copyright and "speech" is therefore easier to see than the relationship between speech and other laws. This point is true but insubstantial. That we are more aware of copyright's effects on speech does not mean those effects are larger or more constitutionally significant than the effects of other laws. ${ }^{117}$

When real property laws prevent protestors from demonstrating on the front lawn of a politician or business executive whose policies they oppose, those laws restrain speech. ${ }^{118}$ It is pointless to pretend otherwise. One might

115. E.g. Cohen v. Cowles Media Co., 501 U.S. 663 (1991) (holding that promissory estoppel claim is not preempted by the First Amendment).

116. Alexander, supra note 98 , at 929 .

117. One could say, as is often said, that "information is both input and output of its own production process." Benkler, Information Production, supra note 1, at 83. This is an important point, but information is far from the only input to the production of information. There are lots of other inputs, too, and the exercise of exclusive rights in things like office space, computers, and printers can silence a speaker every bit as effectively as copyright. The question is then why, at this very abstract level of input analysis, these things should be treated differently for First Amendment purposes.

118. See Virginia v. Hicks, 123 S. Ct. 2191, 2198-99 (2003). 
overlook this fact because we are socialized to accept real property and other laws as "neutral" background regulations that form the social context in which speech analysis occurs, but that is just a flaw in reasoning, not a reason to treat copyright differently. ${ }^{119}$

One could debate whether speech is affected more by copyright, by giving private parties plenary control over homes and office buildings, or by increasing or decreasing the income tax rate. My guess is that other "background rules" are at least as significant as copyright. A tax increase that takes an extra $\$ 1,000$ per year from each household might well do more to cut back on the demand for expression, and thus the dissemination of expression, than a year's worth of infringement actions. Whatever one thinks on such questions, the point remains that such laws have very substantial speech effects, and if effects are what counts, it is not at all obvious that copyright differs from them in ways that threaten free speech values.

Thus, though the Court in Eldred may have been right to reject the appeal to Turner as a basis for "uncommonly strict scrutiny" of copyright, it did not even need to go that far. Apart from the unusual natural monopoly situation at issue in Turner, intermediate scrutiny is just not that strict, and with good reason. Close scrutiny of copyright gains and losses would have to be justified by reasons that do more than point out that the law affects expression. That is a constant.

\section{Why The Normative Critique Faces Insurmountable Problems}

There are both instrumental and nonconsequentialist reasons why the First Amendment cannot be used to regulate Congress's power over copyright. I will start with the instrumental reasons and then discuss nonconsequentialist arguments. The main point in each case is that setting the First Amendment

119. Professor Netanel argues for a strict version of "intermediate" scrutiny on the ground that large rights-holders have too much money and political power and are therefore too successful at getting Congress to favor their interests over the "public" interest, producing laws that "channel" public discourse in a way that favors the rights-holders against the public. Netanel, Skein, supra note 1, at 61-65. The cases he cites for this thesis involve the regulation of cable television. Id. The crucial facts in those cases are the natural monopoly economics of local wireline connections. $I d$. These economic considerations do not translate very well into public choice arguments. All parties with stakes in these cases are rich and influential. Turner upholds a law that favors rich and influential broadcast companies over rich and influential cable companies. Turner Broad. Sys. v. FCC, 512 U.S. 622 (1994). A vote against a law that favors such a party does not signify much, because it is a vote for a law that favors such a party, too. See Whitmore, supra note 100, at 27-28; Samuel R. Olken, The Business of Expression: Economic Liberty, Political Factions and the Forgotten First Amendment Legacy of Justice George Sutherland, 10 WM. \& Mary Bill RTS. J. 249, 355 (2002). 
against copyright produces a conflict between speech interests, rather than between speech and some other interest, such as reputation or order. The First Amendment does not provide premises that can resolve such conflicts.

A. Like Copyright, First Amendment Economics Employs An Ex Ante Approach to the Production of Speech, and Therefore Provides No Basis for Favoring One Speaker Over Another

I will assume here that the purpose of copyright is to promote the production of expression that does not exist yet. Copyright therefore asks what it takes for expression to be produced. It does not take the existence of expression for granted. Neither does the First Amendment. This similarity of emphasis creates a significant problem for the crowding-out argument.

Authors create works continuously. Sometimes they produce works others can copy. In this capacity I will call them upstream authors. Sometimes they draw upon and may copy from existing works. In this capacity I will call them downstream authors. Any given author may be both an upstream and a downstream author at the same time; that may be the ordinary case, rather than the exception. It is therefore very hard to argue coherently that copyright is too generous to upstream authors and too mean to downstream authors. Nevertheless, that is exactly what the copyright crowding-out argument maintains.

To make this argument work, one has to mix together two different perspectives on the production of speech. One perspective, which one might call an ex post view, takes existing speech for granted. References to the public domain and to fair use tend to take existing speech for granted because the public domain only includes works that exist, and fair use can only be made of works that exist. The other perspective, which one might call the ex ante view, is forward-looking. It does not take existing speech for granted. Instead, it asks what conditions have to exist for expression to be produced. It points out that a broad public domain and broad downstream user rights lower the cost of using existing works to create new ones.

It is only from an ex post angle that rights-holders can be tarred as censors. Suppose A publishes a book. B would like to review it, C would like to make a movie out of it, and D would love to play the lead. A is a speaker in one sense of the word - everyone would wave the free speech flag if a government official tried to suppress her book-but in the copyright crowding-out argument A is not "speaking"; she has spoken. If A tried to enjoin B's review or C's movie, or demand, as a condition of assigning the 
derivative right, that anyone but D play the lead, then arguments about "private censorship" would at least be coherent.

The situation is different if A has not yet written. Suppose she can convince everyone she has in her head a book they would want to read. If she petulantly refuses to write it, they can cry all they want, but no one would take seriously the claim that her refusal to write "censored" the work of others. (Following Professor Nimmer, I at least would be more likely to say they should dry their tears and get to work on their own projects rather than relying on the inconstant tempers of other artists.) If B-D got together and contracted with A to write the book, agreeing to give up fair use, first sale, and all other rights the Copyright Act would give them by default, claims of censorship would still ring hollow. If they feel better off without the rights but with the book than in the opposite situation, who is to say they are wrong? ${ }^{120}$

As this illustration shows, how one views the interests of downstream users depends on whether one takes upstream content for granted or takes a forward-looking view and asks how the law can make sure upstream content is produced. The First Amendment embodies a crude economic analysis that is uniformly forward-looking. New York Times $v$. Sullivan is indeed the key case, but not because it shows that laws "which tend to clog the dissemination of matter in the public interest are illegitimate." ${ }^{21}$ Sullivan is the key because it incorporates into First Amendment analysis the assumption that publishers are rational actors who take into account the expected costs of publication when deciding whether to publish.

Sullivan involved a suit by Montgomery, Alabama's Commissioner for Public Affairs. He claimed a fund-raising advertisement that ran in the Times, but which did not name him, defamed him through minor inaccuracies in its description of official Southern oppression of the civil rights movement. ${ }^{122}$ The judge instructed the jury the content was libelous per se and was not privileged; the jury had to decide only whether it was "of and concerning" the Commissioner. ${ }^{123}$ A local, all-white jury decided it was, and awarded the plaintiff $\$ 500,000$ in damages, of which he had offered no evidence. ${ }^{124}$

120. I concede that this example does not account for positive or negative externalities generated by the hypothetical work.

121. Goldstein, supra note 1, at 995.

122. N.Y. Times Co. v. Sullivan, 376 U.S. at 254, 258-59 (1964). For example, the ad claimed student protestors sang "My Country, 'Tis of Thee"' on the steps of the State Capitol; they had sung the National Anthem. Id.

123. $I d$. at 262

124. Id. at 256,260. On the composition of the jury, see Anthony Lew is, MAKE No Law 27 (1991). The plaintiffs struck the two prospective black jurors. The names of the selected jurors and their 
Sullivan has become a free speech icon, but for purposes of the copyright crowding-out argument it is best to remember its context. ${ }^{125}$ It was only one of several cases in which Southern officials used defamation suits to secure from such juries damage awards that would threaten Northern media with bankruptcy and thereby deter such media from covering Southern oppression of the civil rights movement. ${ }^{126}$ If successful, the strategy would have raised the expected cost of covering the civil rights movement and, by basic economic reasoning, reduced national coverage of the movement and, therefore, national pressure on the South to change its ways. That is what the Court had in mind when it worried that the "fear of damage awards" under Alabama's stringent libel law "may be markedly more inhibiting than the fear of prosecution under a criminal statute." 127

The Sullivan Court scuttled this strategy by subjecting libel doctrine to First Amendment scrutiny. To lower the risk that a judge or jury would mistakenly condemn non-libelous speech, the Court held that in defamation claims brought by public officials (later expanded to public figures) the plaintiff had to show the defendant acted with "actual malice," meaning with knowledge that a factual statement regarding the plaintiff was false or published with "reckless disregard" for the truth or falsity of such a statement. ${ }^{128}$ In economic terms, a lower risk of being held liable for libel translated to a lower expected cost of covering controversial stories. Given the now-constitutional assumption that publishers are rational economic actors who rationally discount risks, the Court could expect that lowering the expected cost of publishing marginally libelous content would increase the production of such content. ${ }^{129}$

photographs were printed in a local newspaper before the trial. Id.

125. The story of the case and this context is well told in LEWIS, supra note 124; TAYLOR BRANCH, Pillar of Fire 42-45, 204-09 (1998). It is no accident that even though the Court created a new standard for liability, it did not remand for a new trial under that standard. It decided the case itself, on two different grounds, just to be sure. Sullivan, 376 U.S. at 285-91.

126. That is why the Court noted that only thirty-five of the 650,000 copies of the Times that day were sold in Montgomery County, and that the Times received $\$ 4,800$ for running the ad. Sullivan, 376 U.S. at $260 \mathrm{n} .3$. At the time of trial, four other libel suits based on the advertisement had been filed against the Times. One jury handed down another $\$ 500,000$ plaintiffs' verdict and demands in the other cases amounted to $\$ 2$ million. $I d$. at $278 \mathrm{n} .18$.

127. Id. at 277 .

128. Id. at 280 .

129. As Frederick Schauer has put it, "New York Times, and indeed the entire constitutionalization of American defamation law, is based on the assumption that if the publisher is at financial risk, then this risk will filter down to the editorial department, with a consequent inhibiting effect on the content of the newspaper." Frederick Schauer, Uncoupling Free Speech, 92 CoLum. L. ReV. 1321, 1329 (1992). For a more general explanation of this point, see Daniel A. Farber, Free Speech Without Romance: Public 
At first blush, this consideration seems to support First Amendment limitations on copyright. One of the main points of the free speech critique is that giving upstream authors long and strong rights raises the costs of downstream speakers who would like to copy from earlier works. ${ }^{130}$ The more the Constitution cuts back on copyright, the more downstream speakers save on expression they use as an input to their own work, just as cutting back on libel reduced the expected cost of producing marginally libelous speech. What could be better?

Expected cost is only half the story, however. A rational publisher does not consider expected costs abstractly: she considers them relative to expected revenues. Not surprisingly, the First Amendment cares about speakers' revenues as well as their costs. Statutes confiscating earnings from a convict's sale of his "true crime" story violate the First Amendment, ${ }^{131}$ as do discriminatory taxes ${ }^{132}$ and some discriminatory subsidies. ${ }^{133}$

In this respect, the First Amendment is very similar to copyright law. ${ }^{134}$ The economic aspect of free speech doctrine is forward-looking. It takes the perspective of a hypothetical, economically rational speaker considering whether to produce expression. Within that perspective, it assumes this speaker sees revenues as good and costs as bad. On these assumptions, the Court can predict that speakers will respond to rules protecting revenues or lowering costs by producing more expression than they would without such rules.

If lowering one speaker's costs lowers another's revenues, however, this logic no longer holds. That is the ex ante problem for the copyright crowdingout argument. If the Court uses the First Amendment to limit upstream authors' rights, it might lower downstream speakers' costs by allowing them to use more expression without paying for it. The same limitation, however,

\footnotetext{
Choice and the First Amendment, 105 HARv. L. Rev. 554, 568-69 (1991).

130. See, e.g., Netanel, Civil Society, supra note 1, at 362.

131. Simon \& Schuster, Inc. v. Members of N.Y. State Crime Victims Bd., 502 U.S. 105, 123 (1991).

132. Minneapolis Star \& Tribune Co. v. Minn. Comm'r of Revenue, 460 U.S. 575, 592-93 (1983).

133. Ark. Writers' Project, Inc. v. Ragland, 481 U.S. 221, 234 (1987). The qualification is due to the confused body of law governing the degree to which a subsidy entitles the government to control expression within a subsidized program. Cases suggesting signi ficant government latitudeinclude National Endowment for the Arts v. Finley, 524 U.S. 569, 590 (1998), and Rust v. Sullivan, 500 U.S. 173 (1991). Cases suggesting the opposite include FCC v. League of Women Voters, 468 U.S. 364, 402 (1984), and Legal Services Corp. v. Velazquez, 531 U.S. 533, 549 (2001).

134. See Harper \& Row, Publishers Inc., v. Nation Enters., 471 U.S. 539, 558 (1985) (“[T]he Framers intended copyright itself to be the engine of free expression. By establishing a marketable right to the use of one's expression, copyright supplies the economic incentive to create and disseminate ideas.").
} 
would tend to lower upstream authors' expected revenues. ${ }^{135}$ The Court's assumptions would then produce conflicting predictions about how such a rule would affect the production of speech; doctrines based on such assumptions also would conflict, leaving no First Amendment premise to favor upstream authors over downstream authors, or vice versa. From a forward-looking perspective, the crowding-out argument turns authors into a constitutional "PushmePullyou." Analysts might favor one head or another, but there is no reason to think the animal as a whole has a preference.

One could try to improve free speech economics by refining the crude rational actor assumptions to account for things like diminishing returns over time. Refinement requires data, however, not gross presumptions about human behavior. Whatever else it may do, the First Amendment neither provides data to courts nor gives them a way to gather it. That is why the Court has consistently insisted that Congress is better suited to evaluate economic questions such as how technology affects expected returns. ${ }^{136}$

In addition, refinement at the First Amendment level, rather than within copyright, would imply some important doctrinal changes. Criminal authors' revenues could be confiscated after some period adequate to assure that their production costs were covered. The economic cost of work is defined by the wage one could earn in alternative jobs. Because prisoners have no high-wage alternatives, the cost of their labor would be covered almost immediately, and Simon \& Schuster should either be reversed or severely limited. Taking

135. Technically, the size of this difference depends on downstream authors' license reservation prices and on transaction costs. If a downstream author would not license in a world without First Amendment limitations, then imposing such limitations does not cost the upstream author anything. The same point holds for downstream authors who would be willing to license but who face transaction cost barriers. In some cases, a First Amendment limitation on copyright probably would induce some production that would not otherwise occur, which would not diminish upstream authors' revenues. In other cases, such a limitation would shift revenues from upstream producers to downstream producers. Which of these effects would be greater is an empirical question we will not be able to answer. Reservation prices depend in part on the legal rule structure, so we could not test such effects without first changing the law. The safest assumption is that increasing downstream authors' rights will produce a non-linear reduction in upstream authors' revenues. That should not matter for free speech purposes, however. It would be no defense to a law limiting an upstream author's revenues that downstream authors gained more than they lost. Even in its more utilitarian doctrines, the First Amendment demands more from a law than KaldorHicks efficiency.

136. E.g., Eldred v. Ashcroft, 123 S. Ct. 769, 782 n.5 (2003) (“calibrating rational economic incentives ... is a task primarily for Congress, not the courts"); Sony Corp. v. Universal City Studios, Inc., 464 U.S. 417, 431 (1984) ("Sound policy, as well as history, supports our consistent deference to Congress when major technological innovations alter the market for copyrighted materials. Congress has the constitutional authority and the institutional ability to accommodate fully the varied permutations of competing interests that are inevitably implicated by such new technology.”). 
declining marginal utility into account, one might argue that a large publisher might be taxed at higher effective rates than small publishers; Minneapolis Star Tribune might have to be reversed or qualified, too.

This analysis applies to remedies and procedural rules, too. Arguments that temporary restraining orders and preliminary injunctions must be subject to prior restraint safeguards because "copyright law restricts speech"137 implicitly take an ex ante view of the defendant and an ex post view of the plaintiff. Professors Lemley \& Volokh respond to the ex ante argument by saying speech protective procedural rules are needed "to make sure that even substantively valid speech restrictions don't end up restricting speech that should remain protected." 138

Whether to treat copyright as a restriction is the issue, however, not the answer. To the upstream author considering whether to invest in expression, copyright is a promise, not a restriction. It could be analogized to other rules that help secure investments in expression, such as the promise implicit in real property law that the police will evict trespassers or arrest vandals. The promises implicit in such laws may later be enforced by state action that restricts speech, but not all such laws are treated as prior restraints. (Trespass almost never is. ${ }^{139}$ ) Whether to characterize state action to enforce such laws is a choice that has to be justified with reasons, not declared as obvious.

Ultimately the procedural argument comes down to a desire to err on the side of speech when an error is possible. ${ }^{140}$ In infringement cases, however, all errors favor speech and all costs, including error costs, are costs to speech. Because prior restraint doctrine aims at reconciling speech and non-speech interests, such as security or decency, there is no particular reason to believe it is the best regime to govern copyright, nor to believe the First Amendment requires that it be applied in copyright cases. ${ }^{141}$

137. Lemley \&Volokh, supra note 1 , at 165.

138. Id. at 188 .

139. The rarity of the occasional case in which trespass is treated as a prior restraint, such as Marsh v. Alabama, 326 U.S. 501, 508 (1946), simply highlights that the contrary result is normal. See Lloyd Corp., Ltd. v. Tanner, 407 U.S. 551, 570 (1972); Adderley v. Florida, 385 U.S. 39, 48 (1966).

140. Lemley \& Volokh, supra note 1, at 211 ("If a judge can, at the time of the preliminary injunction hearing, make a reliable finding that the speech is constitutionally unprotected, rather than just that it might be unprotected, then there should be no problem with issuing the preliminary injunction.").

141. Professors Lemley \& Volokh mention the idea that defamation might silence the target of defamatory speech, thus converting defamation cases from a conflict between speech and reputation to a conflict between speech and speech. Id. at 188-89. They note that Justice White advanced such an idea in Gertz v. Robert Welch, Inc., 418 U.S. 323, 400 (1974) (White, J., dissenting). Professors Lemley and Volokh are justifiably skeptical of that argument, but I believe they misunderstand the significance of the Court's treatment of it. The Gertz Court did not consider libel as presenting a conflict between speakers 
Against my analysis so far, one might say the First Amendment protects some downstream speech that both draws on upstream speech as an input and may reduce the upstream speaker's revenues. Unfavorable reviews and parodies exemplify the point. When courts say things like "copyright does not immunize a work from comment and criticism," 142 they take an ex post perspective congenial to the crowding-out critique. Courts deal with such cases as presenting copyright problems, not free speech problems, however, though they sometimes suggest there is a tension between the two. ${ }^{143}$ I note this point here as a qualification on the argument in this section. I will return to it in Part IV.

\section{B. By Themselves, Longer and Broader Rights Do Not Imply Higher Returns On Investments In Expression}

The argument in the last section paves the way for a related point. The copyright crowding-out story stresses that the copyright term keeps getting longer, statutes such as the DMCA give authors the power to prevent the most efficient means of exercising fair use rights, and technology facilitates ever more contracting, which turns consumer surplus into producer surplus. ${ }^{144}$ These points are right. And, all else being equal, longer and stronger rights do in fact imply greater returns to authors and greater costs to consumers and downstream speakers. Even the Copyright Term Extension Act at issue in Eldred generated some positive (though perhaps trivially so) marginal returns. ${ }^{145}$

in which the Court chose one over another. It did what it always does in dignitary tort cases - it ducked the issue by formulating the conflict as one between speech and some other value. In Gertz the other interest was "reputational injury to private individuals." Id. at 348 n.10. In Hustler Magazine, Inc. v. Falwell, 485 U.S. 46 (1988), it was the interest of a target or audience in being free from "an adverse emotional impact." Id. at 55. The Court can duck the issue because the argument is more a prediction of a conflict than an actual conflict. But the Court does not duck the issue as being merely probabilistic. By formulating the conflict as between speech and non-speech values, it refuses to confront the conflict at all. That refusal is telling. The Court refuses to acknowledge even the probabilistic conflict-which may well exist — because it could not deal with that conflict if it had to.

142. Suntrust Bank v. Houghton Mifflin Co., 268 F.3d 1257, 1265 (11th Cir. 2001).

143. E.g. id. at 1263 (holding parody of Gone with the Wind protected by fair use doctrine and saying "[i]n copyright law, the balance between the First Amendment and copyright is preserved, in part, by the idea/expression dichotomy and the doctrine of fair use").

144. E.g. Netanel, Civil Society, supra note 1, at 298-99, 366-71.

145. Which is not to say it generated net positive returns in terms of overall social welfare. I don't know whether it will, though I doubt it. 
Not all else is equal, however. As always, the law is playing catch-up with technology, which makes it easier for millions of people to copy content without paying for it, which millions of people seem quite happy to do. ${ }^{146}$ For Sullivan's rational economic producer, technological change implies more unpaid copying and thus lower expected revenues from investments in expression. That in turn implies that less expression will be produced. ${ }^{147}$

Because technological change affects returns on investment in expression, any given expansion of legal rights may or may not translate into higher producer returns. The average expected return on investment in expression may be higher, lower, or about the same now as it was in 1995 or 1975. The story is probably different for different industries. We simply do not know. We can say, however, that because legal rules are only one of a number of economic factors relevant to investment in expression, copyright expansion does not in and of itself guarantee higher returns on such investments.

For these reasons, pointing to longer and stronger rights for upstream authors does not show that those authors are richer, or consumers/downstream producers poorer, than they were before. Neither does it show that expanding copyright harms First Amendment values. Upstream authors are still authors for First Amendment purposes, and the First Amendment cares about the revenues of all authors. Netting all these effects requires more refined and more empirical analysis than the crude behavioral assumptions driving free speech economics, a job courts are particularly ill-equipped to perform. ${ }^{148}$ Because changes in the law are only one part of the expected-return analysis, the crowding-out argument does not provide a basis for using the First Amendment to limit Congress's copyright power.

\section{The Instrumental Predictions of the Free Speech Critique Are Uncertain, and Create Conflicts the First Amendment Cannot Resolve}

A main point of the copyright crowding-out critique is that using the First Amendment to temper copyright law will improve the content of public discourse and the degree to which people participate in it. The first point

146. See A\&M Records, Inc. v. Napster, Inc., 239 F.3d 1004, 1013-14 (9th Cir. 2001).

147. It might be most accurate to model unpaid copying as increasing the risk and thus the discount rate associated with return to investments in expression. The riskier a revenue stream is, the less it is worth, implying that unpaid copying produces marginal reductions in the output of expression relative to a world with strong anti-copying laws.

148. The Court thinks so, too. Eldred v. Ashcroft, 123 S. Ct. 769, $782-83$ (2003); Sony Corp. v. Universal City Studios, Inc., 464 U.S. 417, 431 (1984). 
refers to the robustness thesis, the second to the passivity thesis. This section shows that the First Amendment provides no basis for concluding that public discourse needs improving or has improved. It also shows that this aspect of the copyright critique creates conflicts the First Amendment cannot resolve. Finally, it shows that the passivity thesis is in tension with the robustness thesis, if it does not contradict it, and deals with only one side of the free speech values it implicates.

1. The Cost of Expression Trades Off with the Number of Speakers and the Variance of Content

As I noted earlier, the robustness thesis can be understood through Justice Black's opinion in Associated Press v. United States. ${ }^{149}$ Professor Netanel cites the case for his "Free Speech Principle," and Justice Black's opinion is cited in other, similar arguments as well. ${ }^{150}$ Justice Black's opinion says the First Amendment values "the widest possible dissemination of information from diverse and antagonistic sources."

To make things a little more concrete, I will interpret the "widest possible dissemination" language to refer to the average cost of expression. The cheaper speech is, the more demand for it there will be. The cheaper and easier speech is to get, the more robust discourse is. I will interpret "diverse and antagonistic sources" to refer both to the number of speakers and the degree of ideological variance among them, as well as to the variance of a notional distribution of content they produce. ${ }^{152}$ The more speakers there are, and the more they disagree with each other, the more robust public discourse is.

These variables conflict with each other, and Justice Black's opinion for the Court in Associated Press provides an excellent illustration of the conflict.

149. 326 U.S. 1 (1945).

150. It is cited in, among other works, Benkler, Free, supra note 1, at 366-67; Rebecca Tushnet, Copyright as a Model for Free Speech Law: What Copyright Has in Common with Anti-Pornography Laws, Campaign Finance Reform, and Telecommunications Regulation, 42 B.C. L. REv. 1, 57 n.185 (2000).

151. Associated Press, 326 U.S. at 20.

152. In other words, imagine a thought experiment in which one could establish a mean for public discourse (perhaps simply setting the most popular content as the mean) and measure how far from the mean the range of protected expression extended. It is possible for speakers with diverse viewpoints to produce similar content. Imagine a history of slavery written by a libertarian economist and a rigorous Marxist historian. There would be differences, but there would also be similarities on economic issues. For a general analysis of product differentiation and copyright, see Christopher S. Yoo, Copyright and Product Differentiation, 79 N.Y.U. L. REv. (forthcoming 2004). 
Associated Press is an antitrust case about a joint venture bylaw that allowed existing members of the Associated Press ("AP") to oppose membership applications from competing papers. Such opposition made it harder and more expensive for competitors to join the AP than for non-competing papers. ${ }^{153}$ The Court affirmed a three-judge trial court order granting summary judgment for the government. ${ }^{154}$

The facts of Associated Press provide little support for Justice Black's free speech rhetoric. The case had nothing to do with preserving diverse and antagonistic viewpoints. The government challenged the AP bylaws to make it easier for non-member papers to join the AP so that those papers could distribute two things: (i) truly homogenous content produced and edited centrally by AP; and (ii) reprinted stories produced by AP members in other cities. ${ }^{155}$ Far from dealing with diverse and antagonistic viewpoints, the case is about the government lowering the cost for non-member papers to tap into and reproduce a flow of mainstream and partly homogenous expression. ${ }^{156}$

Ironically enough, the Associated Press decision probably reduced the number of newspapers that might have produced antagonistic and diverse viewpoints had they not been scrambling for access to relatively homogenous content. The district court found that some of AP's restrictions promoted competition among news networks, though others impeded it. ${ }^{157}$ Judge Hand acknowledged that some aspects of the bylaws were justifiable, but he ordered AP not to discriminate against competitor applicants anyway. ${ }^{158}$ His opinion

153. The bylaw certainly looks bad on its face, but there were two other comparable newspaper syndicates (United Press and the International News Service), and twenty to thirty other news agencies of various kinds, vying for the business. Many papers belonged to both AP and UP. United States v. Associated Press, 52 F. Supp. 362, 366-67 (S.D.N.Y. 1943) (L. Hand, J.).

154. Associated Press, 326 U.S. at 4-5.

155. That is why the Court emphasized that the bylaws "tied the hands" of AP members so they "could not and did not sell any part of their news so that it could reach any of their non-member competitors." Associated Press, 326 U.S. at 13. It is why the Court worried about non-member papers being unable "to buy news from the largest news agency, or any one of its multitude of members ...." Id.

156. Some of the news was reprinted from stories written by other member papers. Other news was generated and edited by AP itself, resulting in the widespread distribution of homogenous content. Membership implied only partial homogen eity, however. Article VIII of the AP bylaws required members to share only news that was "“spontaneous in its origin,' but not any other news - especially no news 'which has originated through deliberate and individual enterprise on the part of such member." Associated Press, 52 F. Supp. at 366.

157. "'The growth of news agencies has been fostered to some extent as a result of the restrictions of The Associated Press' services to its own members, but other restrictions imposed by The Associated Press have hampered and impeded the growth of competing news agencies and of newspapers competitive with members of The Associated Press."' Associated Press, 326 U.S. at 12 n.8.

158. United States v. Associated Press, 52 F. Supp. at 373-74. 
referred to "a combination which, though bound to admit all on equal terms, does not do so," $" 159$ followed by a citation to United States v. Terminal Railroad Association, ${ }^{160}$ a compulsory dealing case that has blessed us with the antitrust "essential facilities" doctrine. ${ }^{161}$

Neither the district court nor the Supreme Court adopted this mandatory admission idea as a holding, but neither did they endorse a coherent alternative. Understandably, in light of this muddled direction, the AP gave up on exclusivity and began accepting all qualified papers. ${ }^{162}$ That meant it followed an open architecture policy in a market in which relatively high firstcopy costs of reporting and low marginal costs of reproduction implied significant economies of scale in production, and in which local production of spontaneous news was arguably a natural monopoly. ${ }^{163}$ Consumers who would like to share opinions with others who have read the same story may create some demand-side economies as well. ${ }^{164}$ In terms familiar from current antitrust debates, the Supreme Court's ruling effectively forced AP to become an open standard in a network market. ${ }^{165}$ Membership became more valuable as it provided access to more stories, which it did as membership increased, creating positive feedback. ${ }^{166}$

Positive feedback for the market leader is negative feedback for competitors. ${ }^{167}$ United Press and International began to feel the pressure. They merged in 1958 to create UPI. ${ }^{168}$ As newspapers began to consolidate, ${ }^{169}$

159. Id. at 374 .

160. United States v. Terminal R.R. Assn., 224 U.S. 383 (1912).

161. See id. See generally Philip Areeda, Essential Facilities: An Epithet in Need of Limiting Principles, 58 Antitrust L.J. 841 (1989) (explaining that the "essential facilities" doctrine is usually traced to Terminal R.R.).

162. Donald I. Baker, Compulsory Access to Network Joint Ventures Under the Sherman Act: Rules or Roulette?, 1993 Utaн L. Rev. 999, 1035 ("Under the Court's decree, AP became an open-entry membership joint venture, providing a diversity of services to which most major newspapers subscribed.").

163. Professor Hovenkamp's defense of the decision models newsgathering as a natural monopoly in which papers produce news at the lowest cost by jointly hiring one reporter who produces reports on the assumption that reports are fungible. See Herbert Hovenkamp, Feder al Antitrust Policy: The Law of Competition and its Practice (2d ed. 1999).

164. See Benkler, Siren, supra note 1, at 69; Sushil Bikhchandani et al., Learning from the Behavior of Others, Conformity, Facts, and Informational Cascades, 12 J. Econ. PersP. 151 (Summer 1998) (discussing faddish adoption of information products and ideas); Netanel, Hierarchy, supra note 1, at 1907-08 (referring to consumption economies using the rubric "associative goods").

165. For more on this, see generally Mark A. Lemley \& David McGowan, Legal Implications of Network Economic Effects, 86 CAL. L. REV. 479 (1998).

166. Id. at 494 .

167. Id.

168. Baker, supra note 162 , at 1035.

169. Id. at 1071. Newspaper consolidation required its own exemption from Associated Press style 
competition among papers fell and the victors could afford to drop one of the major news services. ${ }^{170}$ Consistent with network theory, they tended to drop the less popular UPI. ${ }^{171}$ Its fortunes waned. It declared bankruptcy in 1985 and again in 1991, and by 1992 it had only about 200 media clients and about eighteen major daily papers. ${ }^{172}$ The authors of a history of United Press describe the Associated Press case as dealing United Press a "staggering blow it never would overcome." 173

For these reasons, Associated Press does not endorse a coherent free speech principle. No doubt influenced by the small-dealer populism that shaded all of his antitrust analysis, ${ }^{174}$ Justice Black did not consider that, on the facts before him, the average cost of expression, and thus the degree of its dissemination and consumption, traded off with the number of speakers. ${ }^{175}$ The speakers he mythologized as "diverse and antagonistic" were in fact before him to get access to cheap, homogenous content. ${ }^{176}$

The facts that deflate Justice Black's populist rhetoric present a general conflict among the values he mentioned. Consider the example of the size and concentration of media firms. The Associated Press history confirms there are large economies of scale in producing and consuming content. ${ }^{177}$ To the extent firms grow and merge with other firms to capture such economies, social welfare is increased. ${ }^{178}$ Even if producer concentration reduces

review, which Congress granted in 1970 with the Newspaper Preservation Act, 15 U.S.C. $\S \S 1801-04$ (2000).

170. Baker, supra note 162 , at 1071.

171. $I d$.

172. Id. at 1035 .

173. Gregory Gordon \& Ronald D. Cohen, Down to the Wire: Upi's Fight for Survival 17 (1990).

174. On Justice Black's populism, see generally Roger K. Newman, Hugo Black 6-7, 13 (1994); see also Justice Black Dies at 85; Served on Court 34 Years, N.Y. Times, Sept. 25, 1971, at A1, available at http://www.nytimes.com/learning/general/onth isday/bday/022 7.html (last visited Dec. 5, 2003). At the height of the mid-1960s small-dealer merger rulings, Fortune magazine reportedly dubbed Black's relentless opposition to mergers "Antitrust in a Coonskin Cap." Arthur Austin, Book Review, 56 U. CIN. L. Rev. 193, 203 (1986).

175. Cf. Patterson, supra note 1, at 6 ("While copyright's constitutional purpose-the promotion of learning - is clear, it is not clear whether this purpose is better served by encouraging the creation or by encouraging the distribution of works."). Professor Patterson favors distribution, but I am not persuaded that the First Amendment embodies that preference.

176. Associated Press v. United States, 326 U.S. 1, 20 (1945).

177. This is particularly true for vertically integrated firms. Christopher S. Yoo, Copyright and Democracy: A Cautionary Note, 53 Vand. L. Rev. 1933, 1952 (2000).

178. Surplus may be divided in a number of ways, but it will not be wasted. It may go to consumers in the form of lower prices reflecting lower production costs; it may go to shareholders in the form of higher share prices reflecting higher profit; it may be reinvested in new projects. None of these outcomes is bad 
variance in expression, that conclusion would only pose a conflict between variance and the average cost of expression, which should be lower for firms that achieve economies of scale. By extension, measures designed to reduce media concentration might sacrifice marginal mainstream works for highvariance works. Because the Associated Press Court did not acknowledge this trade-off, much less resolve it, it is of no help on this point.

2. It Is Not Clear Whether or How the Number of Speakers Affects the Variance of Expression

The robustness thesis predicts that relatively weak upstream rights and relatively strong downstream rights will increase the number of speakers, which in turn is presumed to increase the variance of expression. ${ }^{179}$ In fact, the number of speakers may or may not affect the variance of expression. ${ }^{180}$ The question is an empirical one, on which the evidence is mixed.

Professor Netanel acknowledges that "the number of media owners and outlets need not necessarily correlate with diversity of expressive product." 181 He nevertheless believes there probably is, at some level, an inverse relation between diversity of expression and producer concentration. ${ }^{182}$ Professor Benkler also believes there is a relationship between media concentration and content diversity, and he agrees it is not smooth. ${ }^{183} \mathrm{He}$ cites the experience with the FCC's financial interest and syndication rules (FinSyn) as showing that "small variations in the number of outlets or their ownership do not translate into content diversity." 184 Nevertheless, he believes large increases in the number of outlets (such as channels) will produce more diverse expression. ${ }^{185}$

Others are more skeptical. ${ }^{186}$ A famous analysis predicts a monopoly market will produce more varied content than a competitive market, because competitors will try to steal each other's audience by mimicking popular shows. ${ }^{187}$ Later studies have complicated these results, suggesting the

\footnotetext{
news for the production of expression.

179. See supra notes 51-56 and accompanying text.

180. See supra notes 51-56 and accompanying text.

181. Netanel, Market Hierarchy, supra note 1, at 1894.

182. Id. at 1895 .

183. Benkler, Siren, supra note 1, at 96-97.

184. Id. at 96 .

185. Id. at 97.

186. For a recent summary of the relevant sources, see Yoo, supra note 177.

187. Peter O. Steiner, Program Patterns and Preferences, and the Workability of Competition in
} 
distribution and intensity of consumer preferences affect the variance of content produced, ${ }^{188}$ as does the number of channels available for the distribution of content, ${ }^{189}$ and the degree to which content is funded by advertising rather than sales revenues. ${ }^{190}$

The relationship will also differ for different markets that deal in copyrighted works. Wires may be a natural monopoly at the local level, creating the type of distribution bottleneck that drove analysis in Turner, ${ }^{191}$ but newspapers, books, and records do not face that problem. Newspapers and broadcast media sell readers to advertisers, but books do not and movies only do so marginally through product placement. ${ }^{192}$ Selling readers to advertisers may tend to homogenize some content, but it might also make possible the production of niche content for target audiences advertisers wish to reach, which may explain the huge number of magazines targeted to very small audiences. ${ }^{193}$

These considerations call into question the flat presumption of Justice Black's rhetoric in Associated Press. They force us to ask whether we should read Justice Black as stating an empirical prediction, in which case the contours of First Amendment protection will change with our understanding of the relation between concentration and content, or an article of his own populist faith. If it is the latter, which is my guess, one must wonder how far economic populism is a free speech value, and how far it survives Sullivan's introduction to First Amendment law of the rational actor assumption and the crude economic analysis it supports. ${ }^{194}$

Associated Press does not acknowledge such questions, much less answer them. It would be hard to defend nonconsequentialist preferences for small speakers over big ones. ${ }^{195}$ To the extent data are relevant, we again face the problem that the Court is ill-suited to gather them and the First Amendment provides no internal tools to evaluate them, which is why the Court consistently says those jobs are within Congress's domain.

Radio Broadcasting, 66 Q.J. Econ. 194 (1952).

188. Jack H. Beebe, Institutional Structure and Program Choices in Television Markets, 91 Q.J. ECON. 15, 15-17 (1977).

189. Yoo, supra note 177, at 1950-51; Matthew L. Spitzer, Justifying Minority Preferences in Broadcasting, 64 S. CAL. L. REv. 293, 310-11 (1991).

190. Baker, supra note 1, at 336.

191. See supra text accompanying notes 101-04.

192. E.g. Baker, supra note 1, at 333-37.

193. Id. at 336 .

194. Actually, the credit goes to Speiser v. Randall, 357 U.S. 513 (1958).

195. See infra Part IIID. 


\section{Weakening Authors' Rights and Strengthening Users' Rights Might Lead to More Homogenous Expression}

The question in the last section was whether the number of speakers affects the variance of expression. In one respect, that analysis is tangential to the free speech critique of copyright. Other than noting that in some circumstances competitors might try to mimic popular shows, the analysis did not consider the relationship between existing content and downstream production decisions. Variables other than copyright, such as the number of channels available for distribution, played an important role in the analysis.

Copying is what the free speech critique of copyright is all about, however. Downstream users can crib ideas from existing works and try to steal market share all they want, so long as they do not copy expression. This point extends even to the derivative right, which gets a lot of attention in the copyright critique. "[A] work is not derivative unless it has been substantially copied from the prior work." "196 That copying is our subject implies important things for both the robustness thesis and the passivity thesis. I will deal with robustness in this section and passivity in the next.

Using the First Amendment to give upstream authors weak rights, and users/downstream authors strong rights, might lead to more homogenous expression than we have now, the opposite of the result the robustness thesis predicts. Consider this stylized example. There are two possible copyright regimes. The first gives users broad rights to copy. There is a short term, no derivative right, a broad conception of "idea," a relatively literal conception of "expression," a broad conception of fair use, and a rule that rights-holders can only recover such damages as they can prove; they never get injunctions. I will call this "Downstream Authors' Law."

The opposite combination is closer to what we have - an essentially perpetual term, a derivative right, and injunctions as the presumptive remedy for infringement. In this regime, only parodies that attack a work, reviews, and scholarly commentary can be produced without a license. I will call this the "Upstream Authors' Law." The Downstream Authors' Law makes copying cheap. Fewer works are protected by copyright, the lack of a derivative right means anyone can turn any work into something else, and the

196. Litchfield v. Spielberg, 736 F.2d 1352, 1357 (9th Cir. 1984); see also H.R. ReP. No. 94-1476, at 62 (1976) (“' $[\mathrm{T}]$ o constitute a violation of section 106(2), the infringing work must incorporate a portion of the copyrighted work in some form ...."). 
cost of proving damages will make infringement actions less likely. The Upstream Authors' Law makes copying expensive.

I will assume two types of authors: original authors, who can produce works without copying, and as to which no credible infringement claim could be made, and derivative authors, who can only produce works by copying from existing works. That assumption implies two types of expression, which I will call "original" expression and "borrowing" expression. Original expression refers to expression that would not infringe any rights, even under the relatively restrictive standards of the Upstream Authors' Law. Borrowing expression is expression that copies enough from existing works to create a serious risk of infringement liability (and thus relatively high expected costs of production) under the Upstream Authors' Law, but not under the Downstream Authors' Law. I will assume each type of author has a limited amount of time to produce works, and that (infringement risk aside) it is cheaper to produce borrowing expression than original expression. Both types of authors are rational actors; they maximize either personal artistic integrity or profits.

Under either law, integrity-maximizing original authors would produce original expression. Because borrowing is cheaper than writing original expression, profit-maximizing original authors would produce less original expression under the Downstream Authors' Law than under the Upstream Authors' Law. The lower cost of borrowing expression therefore might increase the total quantity of expression original authors produce, but more of it would be copied. ${ }^{197}$ Derivative authors would produce little or no expression under the Upstream Authors' Law. Under the Downstream Authors' Law they would produce the amount of borrowing expression that maximized either their integrity or their profits. Here is a table illustrating these assumptions.

197. Which might make original content more costly to find, reducing the degree to which original expression was actually consumed, as opposed to produced. 


\begin{tabular}{|l|l|l|l|l|}
\hline & $\begin{array}{l}\text { Integrity- } \\
\text { maximizing } \\
\text { original } \\
\text { authors }\end{array}$ & $\begin{array}{l}\text { Profit- } \\
\text { maximizing } \\
\text { original } \\
\text { authors }\end{array}$ & $\begin{array}{l}\text { Integrity- } \\
\text { maximizing } \\
\text { derivative } \\
\text { authors }\end{array}$ & $\begin{array}{l}\text { Profit- } \\
\text { maximizing } \\
\text { derivative } \\
\text { authors }\end{array}$ \\
\hline $\begin{array}{l}\text { Downstream } \\
\text { Authors' Law }\end{array}$ & $\begin{array}{l}\text { Produce } \\
\text { original work }\end{array}$ & $\begin{array}{l}\text { Produce profit- } \\
\text { maximizing } \\
\text { mix of original } \\
\text { and borrowing } \\
\text { work }\end{array}$ & $\begin{array}{l}\text { Produce } \\
\text { borrowing } \\
\text { work }\end{array}$ & $\begin{array}{l}\text { Produce } \\
\text { borrowing } \\
\text { work }\end{array}$ \\
\hline $\begin{array}{l}\text { Upstream } \\
\text { Authors' Law }\end{array}$ & $\begin{array}{l}\text { Produce } \\
\text { original work }\end{array}$ & $\begin{array}{l}\text { Produce } \\
\text { original work }\end{array}$ & $\begin{array}{l}\text { Produce little } \\
\text { or nothing (to } \\
\text { the degree of } \\
\text { indifference to } \\
\text { expected cost) }\end{array}$ & $\begin{array}{l}\text { Produce little } \\
\text { or nothing (to } \\
\text { the degree of } \\
\text { indifference to } \\
\text { expected cost) }\end{array}$ \\
\hline
\end{tabular}

Because profit-maximizing original authors would shift to some borrowing expression under the Downstream Authors' Law, that regime produces a relatively more homogenous set of publicly available expression than the Upstream Authors' Law. ${ }^{198}$ Whether the Downstream Authors' Law would produce more homogenous expression overall than the Upstream Authors' Law would depend on: (i) the ratio of profit-maximizing original authors to integrity-maximizing original authors; (ii) the ratio of original authors to derivative authors; and (iii) the amount of borrowing under the Downstream Authors' Law.

This illustration points out that if we take a purely instrumental analysis, in which authors are not valued as persons but as inputs to the goal of obtaining the greatest "diversity" in expression, then broadening the right to copy someone else's work is a risky policy approach. By making unlicensed copying illegal, the Copyright Act forces authors to do their best to tell their own stories in their own words rather than say, at least in part, what someone

198. The problem is similar to choosing between competition policies that favor intra-standard competition over inter-standard competition. See Joseph Farrell \& Michael L. Katz, The Effects of Antitrust and Intellectual Property Law on Compatibility and Innovation, 43 ANTITRust Bull. 609 (1998). 
else already said. ${ }^{199}$ That approach might produce more diversity in expression than a pro-copying regime.

This illustration does not prove that the robustness thesis defeats itself. It does suggest that we cannot show through a priori reasoning whether it does or not. We do not know how many authors might be empowered by broad user rights and how many might turn into copying machines. Thus, even if the First Amendment values variance in the production of expression, and prefers variance to cheapness if the two conflict, telling a judge to maximize variance still does not tell her what to do with the copyright law.

Suntrust Bank v. Houghton Mifflin Company ${ }^{200}$ provides a more concrete example. The court in that case reversed a district court order enjoining publication of The Wind Done Gone, a book written by Alice Randall as a parody of Gone with the Wind. ${ }^{201}$ Was the district court right to enjoin or was the court of appeals right to reverse? If diversity is the aim, rather than some conception of nonconsequentialist rights, and if we are to take a forwardlooking perspective with regard to downstream authors generally, the answer depends on what Ms. Randall would do if she could not copy Margaret Mitchell. Would she vent her anger at Gone with the Wind by writing her own novel? Would she give up on writing altogether? Assuming her time is limited, is discourse more robust if she writes her own novel than if she parodies Gone with the Wind? If she is capable of writing her own novel, would a rule that allows her to copy Margaret Mitchell induce her to forgo her own voice to piggyback on the popularity of Gone with the Wind? Either way, would writing all her own work produce more diversity, less, or the same amount as would exist if she wrote the parody?

I find it very hard to imagine a world in which Alice Randall may not parody the work of Margaret Mitchell. As a matter of copyright policy, The Wind Done Gone is just the sort of thing the fair use doctrine is for. Nevertheless, if we really are to take an instrumental view of content, with diversity as the goal, I do not see how the First Amendment answers the question of to what extent downstream authors should be allowed to copy and to what extent they should be forced to do their own work.

199. This is just a highly stylized static illustration, of course. It does not take into account differences between highly transformative derivative works and mere knock-offs, for example. Even profitmaximizing derivative authors might produce the former under the Upstream Authors' Law. And it would be more realistic to assume a continuum of authors ranging from highly original to highly derivative. That realistic assumption only makes it harder to calculate how different copyright regimes affect content, however.

200. 268 F.3d 1257 (11th Cir. 2001).

201. Id. at 1259 . 
4. It Is Inconsistent with First Amendment Values to Base Copyright Policy on the Premise that Some Speakers Have Too Much Power and Others Have Too Little

Finally, Associated Press-style populism creates serious problems for free speech theory. From what Archimedean point can Congress or the Court decide that big firms speak too loudly and are heard too much, and individuals or small organizations with critical views speak too softly and are heard too little? The problem is both practical-opinions on such questions can be expected to vary - and theoretical. I will take the second problem first.

Democracy implies a government that responds to the will of the people. That will is formed through an endless cycle in which citizens consume expression, consider it, and rely on it in expressing their own views. If the government intervenes in this process to favor some speakers or viewpoints over others, it shapes the demand to which it is supposed to respond. That puts the whole notion of responsiveness at risk. To the extent the government creates the demand to which it responds, one can question how far it is in fact democratic. That is a large part of the reason why the Court is so adamant that the government has no power to enact laws to favor one view or another. ${ }^{202}$ Democratic theory and free speech doctrine require government to act as if citizens are autonomous with regard to the consumption and production of expression. ${ }^{203}$

The practical problems with implementing a populist approach show that the theoretical problems are quite serious. Consider Suntrust Bank v. Houghton Mifflin Company ${ }^{204}$ again. The book was written to attack Gone with the Wind and the supposedly anodyne view of slavery that book depicts. ${ }^{205}$ Is the view that blacks were better off under slavery dominant? Is the view that slavery was a horror underrepresented or marginalized? Or is the point that Gone with the Wind is too powerful in American society and has got to be cut down to size? Has it been?

202. See supra Part II.

203. See Texas v. Johnson, 491 U.S. 397, 416 (1989); Owen M. Fiss, Liberalism Divided: Freedom of Speech and the Many Uses of State Power 37-38 (1996); Robert Post, Equality and Autonomy in First Amendment Jurisprudence, 95 Mich. L. ReV. 1517, 1522-23 (1997); Alexander, supra note 98, at 939 (reviewing Fiss).

204. Suntrust Bank, 268 F.3d 1257.

205. Id. at $1268,1270$. 
From a rights-based perspective these questions do not have to be answered. If robustness really depends on evaluating the mixture of content within public discourse, however, then we have got to know. If Alice Randall's view becomes dominant, then future parodies of Gone with the Wind will be mainstream expression. If non-mainstream expression is weighted more heavily than ordinary fare, future parodies will have weaker free speech claims against the Mitchell estate than Ms. Randall did.

I cannot see how the First Amendment answers any of these questions. It is closer to the truth to say the First Amendment forbids the government from taking a position on these questions. The problem is that the government cannot help it. As Professor Benkler has emphasized, copyright affects the content of publicly available expression because exclusive rights benefit some speakers more than others. ${ }^{206}$ Authors who sell rights benefit more than those who give their content away or use it as a loss leader for complementary services. ${ }^{207}$ Authors who own lots of rights and can use them as inputs may have lower production costs, and therefore benefit more than those who own few rights and have to license inputs. ${ }^{208}$

This argument is very powerful. It implies that any regime of exclusive rights in expression will affect content; no regime can be neutral. That is indeed, the point we saw earlier when considering whether to treat copyright as a content-based law. ${ }^{209}$ That a neutral law is impossible only means that the lack of neutrality is not much of a criticism of any copyright regime, however. It does not imply that all copyright regimes are equally acceptable in relation to First Amendment values. The question is which set of rules least offend the values the Court has in mind when it warns against content-based regulations.

Laws that give all speakers equivalent legal rights ex ante and allow them to do with those rights what they will better approximate the values the Court has in mind when it refers to content neutrality than does any regime that tries to tinker with rights ex post to make some voices louder and others softer. As we saw in Part II, copyright does not favor viewpoints or subjects. It does not present serious risks of governmental favoritism that might impair public discourse. ${ }^{210}$ Formal ex ante equality is not neutral, but its main distortion

206. Benkler, Constitutional Foundations, supra note 1, at 181.

207. Id.

208. Id. at 181-82. See also Yochai Benkler, Intellectual Property and the Organization of Information Production, INT'L REV. LAW \& ECON. 81, 91-93 (2002); Baker, supra note 1, at 326.

209. See supra text accompanying note 77-88.

210. See supra text accompanying notes $77-88$. 
comes from revenues generated by meeting demand, a source of distortion the government must respect as beyond its power to counter. ${ }^{211}$

This point extends to broader critiques of copyright, which seek to weaken rights as a way of reducing the power and voice of large media firms. On this account, copyright props up big media firms, which can harm democracy by swamping "oppositionist" or "minority" viewpoints, and by creating artificial demand that reflects the kind of content the firm can produce more than it does the "actual" desires of consumers. ${ }^{212}$ The result is a self-reinforcing cycle in which docile consumers have no choice but to suffer through banal content. Because people form preferences in part by consuming expression, the notion that expression responds to preferences is at least partly incoherent. ${ }^{213}$

This critique makes some important points. Copyright is only one part of the story it tells, however, and it is unclear how important a part it is. Small or large, rich or poor, within each category of work speakers get pretty much the same legal rights. ${ }^{214}$ Big firms may have an easier time drawing attention to and making money from content they produce, rather than report (such as spontaneous news), but those economic facts are generated by the way such firms manage rights, not the rights themselves.

This aspect of the passivity thesis is therefore more about a preference for small speakers and a dislike for big companies than about copyright law. ${ }^{215}$ The point of the argument is not so much to strengthen individual speakers - they have nominal legal equality already - but to increase their relative power by weakening the rights, and thus power, of big media firms. The argument levels down, not up, and that creates significant First Amendment problems the argument cannot overcome.

If big producers have lower costs than small, which our earlier analysis suggests they do, then their lower costs imply cheaper speech, which in turn implies wider demand for, and dissemination of, speech, a goal the Associated Press rhetoric endorses. Sullivan makes clear that the First Amendment cares

211. Alexander, supra note 98, at 93 ("[T] $]$ he First Amendment protects a process of citizens' evaluations of information and forbids governmental preemption of that process by privileging certain evaluations.").

212. Benkler, Constitutional Foundations, supra note 1, at 181.

213. Baker, supra note 1 , at 320 .

214. The term of a work for hire differs from the default term, however. Compare 17 U.S.C. § 302(a) (2000) (life of the author plus seventy years) with 17 U.S.C. § 302(c) (120 years from creation or ninetyfive years from publication for a work for hire).

215. There is some relation between the two - rights are what such firms sell and manage — but the egalitarian, anti-corporate aspects of the argument are much stronger than the legal aspects. 
about lowering the expected costs of even large media firms like the New York Times. ${ }^{216}$ The Times is, and was in 1964, a bigger, richer, and more influential player than most of the individuals it covers. Does it follow that the actual malice rule is wrong because it favors the large media firm over the little guy? ${ }^{217}$ If the answer is "no" when speech rights conflict with reputation, why should it be "yes" when two speakers square off? $?^{218}$

That brings us to the most fundamental point. This argument rests ultimately on the premise that the First Amendment requires ex post equality of voice in expression. That is not the law. The First Amendment is instead highly suspicious of government efforts to achieve such equality. As the Court said in Buckleyv. Valeo, "the concept that government may restrict the speech of some elements of our society in order to enhance the relative voice of others is wholly foreign to the First Amendment."219

Mc Connell v. Federal Election Commission arguably modifies Buckley's general approach to campaign finance, but this principle remains good law as a general matter. ${ }^{220}$ For example, when the Court protects a publisher's editorial independence and rejects an open access claim, it rejects ex post equality in favor of preserving the latitude of upstream speakers. ${ }^{221}$ Turner, which provides the best doctrinal hook for the crowding-out argument, carefully distinguished Buckley on the ground that the spending restriction at

216. See supra text accompanying notes 120-28.

217. Cf. Netanel, Skein, supra note 1 (arguing for stricter intermediate scrutiny of laws procured by large rights-holders).

218. Professor Benkler argues on a different point that it is "a moral inversion of the First Amendment" to give corporations speech rights as against individuals, but he recognizes that current doctrine does in fact give media firms full First Amendment protection. Benkler, Constitutional Foundations, supra note 1, at 187-91. The law is right to do so. There is no basis for treating rights held by firms - which are simply one way persons arrange their interactions with each other relative to the production of expression - worse than rights held by individuals. There would be no way to achieve that distinction anyway, since lowering the value of rights held by firms would lower income to persons who sold rights to firms. Professor Benkler's argument also includes the claim that using the First Amendment to limit copyright increases autonomy. Id. at 204-05. For a discussion of these points, see David McGowan, Copyright Nonconsequentialism, __ Mo. L. REv. __ (forthcoming 2004).

219. Buckley v. Valeo, 424 U.S. 1, 48-49 (1976).

220. McConnell v. Federal Election Commission, 124 S. Ct. 619 (2003).

221. See Ark. Educ. Television Comm'n v. Forbes, 523 U.S. 666 (1998) (holding that public television station did not violate Constitution in excluding third party candidate from televised debate); R.A.V. v. City of St. Paul, 505 U.S. 377 (1992) (striking down a statute which enhanced penalties for speech that might terrorize or offend members of certain groups); Miami Herald Publ'g Co. v. Tornillo, 418 U.S. 241 (1974) (holding that newspaper's refusal to print letter to the editor did not violate First Amendment). Both Forbes and Miami Herald said it was important to protect the editorial independence of journalists from mandatory access rules. Forbes, 523 U.S. at 666; Miami Herald, 418 U.S. at 258. 
issue there was unconstitutional because it "was designed to ensure that the political speech of the wealthy not drown out the speech of others."222

The wealth-countering motive Buckley rejected is no less questionable when it aims at copyright than when it aims at other economic variables. If the government taxed or enjoined the expression of Rupert Murdoch's entities on the ground that he had too much power, its motives would offend core First Amendment values. By what logic do those same motives become First Amendment values when they target Murdoch's copyrights?

As we saw earlier, any set of rights in expression will affect content. The only question is how to arrange the rules so they present the least risk to free speech values. As between equality of opportunity ex ante and equality of results ex post, it is truer to First Amendment values to favor the former because such a regime minimizes the degree to which government officials have to evaluate public debate and try to tinker with it to make it better.

\section{Rights-Based Critiques of Copyright Fit Imperfectly with First Amendment Values}

The last three sections dealt with instrumental aspects of the copyright crowding-out argument. This section deals with nonconsequentialist arguments. I will first discuss the passivity thesis, and then Professor Rubenfeld's imagination argument.

\section{Copying Does Not Prevent Passivity}

The passivity thesis holds that copyright gives rights-holders power that places them in authoritarian relationships with users who, within the scope of these relationships, are passive subjects rather than active, autonomous individuals. ${ }^{223}$ Justice Brandeis's famous concurrence in Whitney $v$. California aptly summarizes the values behind the passivity thesis. ${ }^{224}$ The language has been quoted a thousand times, but the passivity thesis provides a fresh perspective on it. I have italicized language that is not usually central to interpretation of this passage. According to Brandeis,

[t]hose who won our independence believed that the final end of the State was to make men free to develop their faculties; and that in its government the deliberative forces

222. Turner Broad. Sys. Inc. v. FCC, 512 U.S. 622, 658 (1994).

223. Netanel, Civil Society, supra note 1, at 345.

224. Whitney v. California, 274 U.S. 357, 375 (1927) (Brandeis, J., concurring). 
should prevail over the arbitrary. They valued liberty both as an end and as a means. They believed liberty to be the secret of happiness and courage to be the secret of liberty. They believed that freedom to think as you will and to speak as you think are means indispensable to the discovery and spread of political truth; that without free speech and assembly discussion would be futile; that with them, discussion affords ordinarily adequate protection against the dissemination of noxious doctrine; that the greatest menace to freedom is an inert people; that public discussion is a political duty; and that this should be a fundamental principle of the American government. ${ }^{225}$

Justice Brandeis suggests that citizens, to be true citizens, must engage actively and as individuals with the political issues of the day. ${ }^{226}$ Citizens must have the courage to think for themselves and speak for themselves. In fact they have a duty - albeit a political rather than legal duty — to do so. The greatest enemy to freedom is not censorship, but an inert citizenry. The opinion invokes images of classical democracy so strong one can almost see an open copy of Zimmern's The Greek Commonwealth by Brandeis's side as he writes the opinion. ${ }^{227}$

With these values in mind, it is easy to see that the passivity thesis suffers from a tension between two conceptions of individualism. One holds that to be an autonomous person one must act autonomously, not copy others. The other holds that no one can be truly autonomous under the thumb of a rightsholder. This tension threatens to render the passivity thesis incoherent. Rosemount Enterprises v. Random House, ${ }^{228}$ and the different ways Professors Nimmer and Goldstein looked at that case, illustrates this point. Recall that in Rosemount the Second Circuit reversed a preliminary injunction blocking release of a biography of Howard Hughes that quoted from magazine articles in which Hughes owned the rights. Professor Goldstein liked the case; Professor Nimmer did not.

According to Professor Nimmer, the defendants in Rosemount could have copied "the facts or ideas of Hughes's life" from the articles or anywhere else "and supplied their own expression." 229 Because the defendants "chose to avoid the expenditure of time and skill necessary to evolve their own expressions, and instead copied the plaintiff's expression, there can be no first

225. Id. (emphasis added).

226. $I d$.

227. Brandeis admired classical sources, and The Greek Commonwealth was his favorite book. Philippa Strum, Louis D. Brandeis: Justice for the People 237 (1984). See also Vincent Blasi, The First Amendment and the Ideal of Civic Courage: The Brandeis Opinion in Whitney v. California, $29 \mathrm{WM}$. \& MARY L. REV. 653 (1988).

228. 366 F.2d 303 (2d Cir. 1966).

229. Nimmer, supra note 1, at 1203. 
amendment justification for [their] copying." ${ }^{230}$ In general, Professor Nimmer saw copying as a cheap out for lazy writers. He believed the First Amendment values authors for their individual perspectives, not as a conduit for the perspectives of others, so it does not value their copying very much. Professor Nimmer's position is echoed in the Eldred Court's comment that copiers advance free speech values to a lesser degree than non-infringing speakers. ${ }^{231}$ On this account, copyright might well enhance autonomy and lessen passivity by forcing authors to be somewhat self-reliant, if only at the minimal level of avoiding infringement. ${ }^{232}$

Professor Goldstein, on the other hand, saw Rosemount as a straightforward case of a rich and paranoid enterprise monopolist trying to squelch expression he did not like. ${ }^{233}$ If copyright let Hughes get away with his scheme, then the author's original work - the vast majority of the book-would be wasted. ${ }^{234}$ That might intimidate prospective authors and scare them off projects for fear they would be sued by crafty moguls like Hughes, who could turn copyright upside down to suppress speech. ${ }^{235}$ That sort of fear might lead to just the subservience Professor Netanel has argued is inconsistent with any decent conception of democracy and with at least some conception of free speech values. ${ }^{236}$

There is a lot of truth to both views. Copying is an attractive option for lazy authors. Just as the twenty-five-year-old who lives at home and expects mom to do the laundry is something less than an adult, there is a sense in which the author who copies, where he can do his own work, is something less than an author. ${ }^{237}$ There is something of the sponge about him, which is not what Justice Brandeis had in mind.

In Justice Brandeis's terms, in what sense does a copier speak as they think; in what sense do they develop their faculties? If it is the individual's contribution that matters, in what sense does copying discharge the duty of political participation? Aren't copiers, to the extent of their copying, inert? And, in response to the intimidation argument at the heart of Professor

230. $I d$.

231. Eldred v. Ashcroft, 123 S. Ct. 769, 789 (2003).

232. As Professor Rubenfeld has put it, "[w]hen copyright law bars simple piracy, it does not punish infringers for exercising their imagination. It punishes them for failing to exercise their imagination-for failing to add any new imaginative content to the copied material." Rubenfeld, supra note 1, at 48.

233. Goldstein, supra note 1.

234. $I d$.

235. $I d$.

236. Netanel, Civil Society, supra note 1, at 345.

237. I discuss the problem of derivative works below. 
Netanel's version of authoritarianism, isn't courage the best guarantor of freedom? Have we no right to expect it of downstream authors? In these ways, Justice Brandeis's classical orientation to democracy is much more individualistic than the free speech critique of copyright. ${ }^{238}$

These are good arguments but they are not conclusive. There is still a lot to be said for the view that courts should not be tools for censorious paranoiacs. It is one thing to be courageous; it is another to spend years of one's life on a project an author can invoke the power of the State to suppress. That crosses over from courage to stupidity, which is not what Justice Brandeis had in mind. And sometimes nothing but copying will do, which was a point Professor Nimmer made about the My Lai photographs and the Zapruder film, but which might be extended to choice bits of J.D. Salinger's letters ${ }^{239}$ and perhaps other biographical material.

The truth in each view creates a copyright version of Scylla and Charybdis. We do not want a copyright law that makes authors subservient lackeys but neither do we want a law that gives them an incentive to be no more than a sponge. But how far can the law demand that authors do their own work before it crushes them? Should the law forbid only literal copying, so the author who calls himself Bos and cannot write anything but Oliver Twiss or Nickelas Nickelbery is free to do so? ${ }^{240}$ Should the law grant authors the right to make derivative works, so any copying is suspect and authors have to buck up and write what they can?

Once there is any prohibition beyond literal copying, such a decision has to be made. The First Amendment does not provide a premise for that decision, however. If anything, it makes the choice more complicated. Does Alice Randall's claim to have been traumatized by Gone with the Wind, ${ }^{241}$

238. I therefore disagree to some extent with Professor Benkler's claim that " $[t]$ he strongest democratic justifications of highly protective copyright serve what [Professor C. Edwin Baker] has described as the elitist conception of democracy." Benkler, Constitutional Foundations, supra note 1, at 182. Strong copyrights also encourage authors to do their own work rather than copy, which is consistent with important aspects of Justice Brandeis's non-elitist vision. A similar point may be made regarding Professor Benkler's criticism of Cass Sunstein's worry that public discourse is fragmenting with decentralized consumption. Professor Benkler points out that Professor Sunstein does not focus on "the productive, rather than the consumption, role that individuals can play." Id. at 186. Perhaps, but Professor Benkler's claim that "proprietary production squelches" individual "yeoman speakers" is overstated. Id. Copyright prohibits copying. Is that what yeoman speakers do?

239. Salinger v. Random House, Inc., 811 F.2d 90, 96 (2d Cir. 1987).

240. Mark Ford, Introduction to Nicholas NickLeby (Penguin ed. 1999).

241. Wendy J. Gordon, Excuse and Justification in the Law of Fair Use: Commodification and Market Perspectives, in The Commodification of Information 171 (Neil W. Netanel \& Niva ElkinKoren eds., 2002) 
carry any weight in such analysis? Can it be given any weight without running afoul of ordinary First Amendment doctrine, which holds that offense is not a basis for a claim against a speaker? ${ }^{242}$ Some people are offended when they see nudity on screen. Does their offense give them a First Amendment right to alter, reproduce, and distribute sanitized versions of movies like Titanic ${ }^{243}$ Directors are offended at Bowdlerization. ${ }^{244}$ Does their offense count?

These questions point out a tension between the robustness and passivity arguments. They also make the passivity thesis look slightly schizophrenic. The only way to deal with this problem is to base the law on an assumption about human behavior, similar to the rational actor assumption behind Sullivan. Unlike that assumption, however, I doubt there is much consensus on whether authors who would copy if given the chance could produce their own work if they have to. The Court could not get away with dropping some assumption into an opinion as little more than a common-sense observation.

Most likely, different authors have different abilities to produce under any given prohibition on copying. Authors themselves may not know their ability until they are put to the test. That means no assumption could be tested until a rule is selected, which means any assumption provides an uncertain basis for selecting the rule. However this assumption gets made, it will be no more than a bet as to what the rule based on the assumption will accomplish. The First Amendment sometimes tells Congress which way it has to bet, but that is not the case here. All these concerns suggest Congress has significant latitude to make one assumption or another without infringing First Amendment values. The law does not have to tell authors to buck up and do their own work but, as Eldred strongly suggests, the First Amendment does not prevent it from doing so.

242. Hustler Magazine, Inc. v. Falwell, 485 U.S. 46, 46 (1988); Cohen v. California, 403 U.S. 15, $15(1971)$.

243. Thomas Nord, Clean Cut: New Services Edit Sex and Violence out of Movie Videos, CouRIER J., Oct. 18, 2002, at 1E, available at http://www.courier-journal.com/features/columns/popculture/ fe20021018pop.html (last visited Dec. 5, 2003); see generally http://www.cleanflicks.com (last visited Dec. 5, 2003).

244. Press Release, Directors Guild of America, DGA Responds and Counterclaims Against Rubert Hunstman and Clean Flicks (Sept. 20,2002), at http://www.dga.org/news/pr_expand.php3?281 (last visited Dec. 5, 2003). 
2. Why Replacing Injunctions with a Damages Rule for Copying and Creating a Right of Imagination Does Not Work

My discussion of the individual aspect of the passivity thesis left out an important type of copying: work by highly transformative users who take existing works and use their imagination to modify or extend those works. These authors have a Lockean claim to what they create on their own, ${ }^{245}$ which means they can advance arguments that have to be taken seriously within what seems to be Congress's quasi-Lockean approach to copyright. ${ }^{246}$ Do they have First Amendment rights as well?

Professor Jed Rubenfeld argues imagination is the key to the relationship between copyright and the First Amendment. ${ }^{247} \mathrm{He}$ proposes "the freedom of imagination" as the First Amendment interest relevant to copyright disputes: "No one may be penalized for what he dares to imagine. What a person can imagine, he may imagine." 248 This argument fits the copyright crowding-out thesis because Professor Rubenfeld believes copyright's encroachment on the First Amendment is the result of the "stunning decrease in the amount of copying that came to be required in literal reproduction cases," and that this decrease foreshadowed the creation of the derivative right. ${ }^{249}$

On this view, a rule prohibiting literal copying raises no free speech worries because, when a government official simply compares two things to see if they are the same, there is no risk of bias against the substance itself. The job is essentially mechanical, and could be done by one who did not understand the language of a work. ${ }^{250}$ Moving beyond literal copying automatically creates problems, however, because then government officials (judges) have to evaluate the product of someone's imagination to determine whether it is lawful. ${ }^{251}$ Thus, while literal copying may be enjoined, once a

245. Derivative authors own what they produce, but not what the upstream author produced, and vice versa. 17 U.S.C. $\S 103$ (b) (2000); Stewart v. Abend, 495 U.S. 207, 223 (1990) ("The aspects of a derivative work added by the derivative author are that author's property, but the element drawn from the pre-existing work remains on grant from the owner of the pre-existing work.").

246. McGowan, supra note 218

247. Rubenfield, supra note 1 , at 37.

248. Id. This principle is implemented by testing the aims of regulations and the motives behind them. See id. at 41 .

249. Id. at 52 .

250. That is why, as we saw in Part II, Professor Rubenfeld does not see the reproduction right as a content-based regulation of expression. See supra Part II.

251. Rubenfeld, supra note 1, at 52-53. 
judge decides the defendant has "reimagined" an existing work the plaintiff may neither enjoin the derivative work nor collect damages. The plaintiff has instead a right for allocation of the defendant's profits. ${ }^{252}$

Imagination is important to the values the First Amendment upholds, but it is not clear there is a right to imagination as such. The First Amendment protects some acts that are much closer to copying than to imaginative expression, such as cross burning, ${ }^{253}$ flag burning, ${ }^{254}$ or distributing someone else's leaflets. ${ }^{255}$ In contrast, the government may regulate all sorts of imaginative expression including, at a minimum, obscenity, ${ }^{256}$ true threats (which may be worse the more imaginative they are), ${ }^{257}$ promises, ${ }^{258}$ and fraudulent statements. ${ }^{259}$

Assuming there is such a right, however, three issues remain. First, any derivative author is free to distribute their own work, without whatever they have copied. ${ }^{260}$ As with literal copiers, who get no rights under Professor Rubenfeld's regime, one could say derivative authors are not being punished for what they did imagine, but for what they did not imagine and copied instead. It is not clear why this logic applies to copiers but not transformative copiers.

Perhaps one could answer this point by saying that literal copying does not present the problem of distinguishing between the contributions of upstream and downstream authors. That is a good response, but it raises the second issue. Professor Rubenfeld's argument does not solve the problem of having government officials pass judgment on imagination. Though he

\section{Id. at 55 .}

253. Virginia v. Black, 123 S. Ct. 1536 (2003).

254. Texas v. Johnson, 491 U.S. 397 (1989).

255. Talley v. California, 362 U.S. 60 (1960). On this point, see generally Volokh, supra note 1.

256. Miller v. California, 413 U.S. 15 (1973).

257. United States v. Hart, 212 F.3d 1067, 1069-70 (8th Cir. 2000) (affirming conviction of antiabortion activist who, after the Oklahoma City bombing, parked Ryder trucks outside abortion clinic).

258. Cohen v. Cowles Media Co., 501 U.S. 663 (1991).

259. Professor Rubenfeld tackles the fraud argument by saying what is punished in fraud is not imagination but the failure to admit that one is exercising imagination. Rubenfeld, supra note 1 , at 45 . This response would be persuasive if there were a rule compelling authors to say whether they are writing fiction. There is no such rule, which would raise significant free speech worries if it were created. To raise but not answer the question whether a work is factual or imagined may be an important part of its point. Fraud is different not because there is a background rule of disclosure but because fraud presumes a social context that creates reliance interests the law recognizes by giving a listener a cause of action rather than giving a speaker a free speech defense. See Post, supra note 76, at 1254-55.

260. They have this right, at least if there is something they have not copied. $C f$. Anderson v. Stallone, No. 87-0592, 1989 WL 206431 (C.D. Cal. Apr. 25, 1989) (finding the author of script for "Rocky IV" had no rights in script in which original material could not be separated from copied material). 
defends an absolute First Amendment right of imagination, ${ }^{261}$ he also says changes from an original text that are too "[t]rivial," "obvious," or which otherwise "involve no substantially new act of imagination" do not get the benefit of the right. $^{262}$ The subjective evaluation Professor Rubenfeld criticizes as part of the derivative right is to some degree replicated in the evaluation of whether a work is a substantially new act of imagination. As he says, "[a]t bottom, the judge is called on to decide whether the old has been reimagined - whether the allegedly infringing new work is in fact new."263

Once one allows the reproduction right to cover more than literal copying, there is no longer an absolute right to imagination. The only question left is how much imagination upstream authors may force downstream authors to exercise to avoid infringement. It is hard to see what tools the First Amendment might provide to make such a determination. Is Alice Randall's choice to write Ashley Wilkes as gay trivial or obvious? ${ }^{264}$

In economic terms, the main difference between current law and the imagination thesis is that Professor Rubenfeld favors a liability rule over a property rule. ${ }^{265} \mathrm{He}$ would not tolerate injunctions against imaginative derivative works but would instead give upstream authors the right to sue for an allocation of the downstream author's profits. As we have seen, the aversion to injunctions has long been part of the crowding-out argument. This aversion needs a greater justification than is commonly provided, however, because to the extent injunctions facilitate bargaining, they are a way of allocating profits.

In many, if not most cases, the threat of injunctive relief can do a good job of forcing bargaining without introducing extraneous variables such as judicial or administrative errors. The parties have better information and incentives than administrators or judges, and more time to devote to studying the effects of particular deals. ${ }^{266}$ For this reason, if a rights-holder is willing to license a derivative work, the parties' bargaining probably better approximates their relative contributions to the work than would any

261. Rubenfeld, supra note 1 , at 37.

262. Id. at 55 .

263. Id.

264. See Suntrust Bank v. Houghton Mifflin Co., 268 F.3d 1257, 1270-71 (11th Cir. 2001).

265. On the difference, see Calabresi \& Melamed, supra note 37, at 1092. Professor Rubenfeld notes that his proposal departs from this approach because it does not allow for injunctive relief, but he does not asses how this departure affects the price-allocation portion of his proposal. See Rubenfeld, supra note 1, at 56 .

266. For more on this difference, see David McGowan, Website Access: The Case for Consent, 35 Loy. U. CHI. L. Rev. 341 (2003). 
administrative scheme. By ruling out injunctions, Professor Rubenfeld undercuts what is arguably the most precise way of ascertaining what a downstream author has brought to the table, at least if profits are to be allocated based on market valuations of the parties' contributions rather than the subjective opinions of judges or administrators. ${ }^{267}$

Indeed, requiring an allocation of profits might actually reduce the amount of speech produced under current doctrine, in which a downstream speaker with a fair use defense does not have to share profits with an upstream speaker. If we suppose a lot of the imagination in The Wind Done Gone comes from Margaret Mitchell - a plausible suggestion for a parody - then a lot of Alice Randall's profits would go to Margaret Mitchell's estate. ${ }^{268}$ The basic economic reasoning of Sullivan suggests this result could squelch the book quite as effectively as any district court order. Professor Rubenfeld is concerned with rights, not policy, ${ }^{269}$ which is understandable, but at least since Sullivan, the First Amendment has been concerned with policy as well as rights.

Finally, it is significant that even the imagination thesis cannot get judges out of the business of evaluating the substance of expression. It might be best to take this fact as a sign that the sort of economically oriented, comparative content evaluation called for by the derivative right and the fair use doctrine advance free speech interests without presenting the risks the Court has in mind when it worries about content-based regulations.

To take one example, it makes economic sense to give greater fair use protection to parodies and other works that attack an existing work than to downstream works that extend an existing story line or use an existing work to attack something else. ${ }^{270}$ Upstream authors are less likely to license attacks on their work than other uses of their work. This reluctance may reflect noneconomic values such as artistic integrity, or just an aversion to seeing Ashley Wilkes in print as being gay. ${ }^{271}$ Where there is reason to believe upstream

267. I am not sure whether Professor Rubenfeld believes the value of imagination should be measured by the demand for the imaginative component - a market-mimicking measure —or through some other means, such as the subjective analysis of the judge or administrator.

268. The case actually settled with Houghton Mifflin contributing an unspecified sum to Morehouse College, with which Mitchell had some connections. See The Associated Press, Settlement Reached over 'Wind Done Gone, 'FreEdom F., May 10, 2002 at http://www.freedomforum.org/templates/document.asp? documentID=16230 (last visited Dec. 5, 2003).

269. Rubenfeld, supra note 1, at 58-59.

270. Richard A. Posner, When is Parody Fair Use?, 21 J. Leg. Stud. 67 (1992) (suggesting narrow scope for fair use that attacks a work, though not for use that uses a work to attack something else).

271. See Suntrust Bank v. Houghton Mifflin Co., 268 F.3d 1257, 1270 (11th Cir. 2001). 
authors' preferences are an unreliable proxy for the welfare effects of particular downstream works, there is less reason to rely on those preferences as a proxy, and less reason to enable bargaining that implements those preferences.

Copyright's relatively unstructured and intrusive analysis therefore may do a better job of mediating between the conflicting needs of authors than the First Amendment would do. To the extent this point holds, it may be important not to consitutionalize copyright so that judges may make such sensible, ad-hoc judgments without having this methodology bleed over into areas of free speech analysis where they would pose a greater threat to First Amendment values ${ }^{272}$ or where congressional fact-finding is preferable to judicial "ad-hoccery." ${ }^{273}$ Regardless whether this is true, however, it is hard to see how the right to imagination shows the way for the First Amendment to limit Congress's copyright power.

\section{Making Sense of the Court's Accommodation Rhetoric}

Up to now, I have not discussed the Supreme Court's description of the relationship between the Copyright Act and the First Amendment. This part tries to make sense of that rhetoric. Following Professor Nimmer, in Harper \& Row Publishers, Inc. $v$. Nation Enterprises,${ }^{274}$ the Court said the idea/expression dichotomy and perhaps the fair use doctrine (the syntax does not make this clear) are "First Amendment protections already embodied in the Copyright Act[]." 275 In Eldred v. Ashcroft the Court said the Copyright Act "incorporates its own speech-protective purposes and safeguards," contains "built-in First Amendment accommodations,"276 and that these "builtin free speech safeguards are generally adequate to address" First Amendment issues the Act might raise. ${ }^{277}$ The Court held that the court of appeals "spoke too broadly" when it said copyrights were immune from First Amendment challenge. But the Court concluded by holding that where, as in the Copyright Term Extension Act ("CTEA"), Congress had not altered "the traditional

272. As might occur if the concept of declining marginal utility of income were applied to standard free speech economics. See Rubenfield, supra note 1, at 21.

273. Cf. Frederick Schauer, Categories and the First Amendment: A Play in Three Acts, 34 Vand. L. REv. 265, 271-72 (1981) (discussing judicial "ad-hoccery" in free speech cases).

274. Harper \& Row, Publishers, Inc. v. Nation Enters., 471 U.S. 539 (1985).

275. Id. at 560 .

276. Eldred v. Ashcroft, 123 S. Ct. 769, 788 (2003).

277. Id. at 789 . 
contours of copyright protection, further First Amendment scrutiny is unnecessary.".278

What on earth do these comments mean? How can a statute "embody," "incorporate" or "buil[d] in" constitutional protections? How would you know whether it had? Isn't it the Constitution that constrains the statute? Why does following the "traditional contours" of copyright protection satisfy the First Amendment? At most one would expect the Court to say the Copyright Act is "consistent with" or "reflects" a limitation that, by hypothesis, exists outside the statute and which the Court could identify, describe to readers, and use to establish that the statute complies with the limitation. The Court has never done that. Instead, the Court's rhetoric regarding the relation of copyright and free speech is noticeably less categorical than its rhetoric in other free speech areas. ${ }^{279}$

In other constitutional decisions over the past several years, the Court has insisted that Congress has no power to determine the parameters of constitutional rights. A little over four months after Justice Ginsburg wrote Eldred, Chief Justice Rehnquist pointed to a line of recent cases, beginning with City of Boerne v. Flores, ${ }^{280}$ which hold that "it falls to this Court, not Congress, to define the scope of Constitutional guarantees." 281 Why does this Court, which thoughtful commentators have accused of grabbing power at the expense of Congress and of rejecting the notion of a dialogue with that branch, ${ }^{282}$ seem so deferential when it comes to copyright?

The Court might mean that the idea/expression dichotomy and fair use doctrines are somehow part of the Constitution, or at least compelled by it. This argument simply will not fly, however. I concede that it is hard to imagine a world in which ideas could be copyrighted, but it is equally hard to imagine where the pressure to do so would come from. ${ }^{283}$ I know of no one

278. Id. at 790 .

279. E.g., Regan v. Time, Inc., 468 U.S. 641, 648-49 (1984) ("Regulations which permit the Government to discriminate on the basis of the content of the message cannot be tolerated under the First Amendment.").

280. City of Boerne v. Flores, 521 U.S. 507 (1997).

281. Nev. Dep't of Human Res. v. Hibbs, 123 S. Ct. 1972, 1977 (2003).

282. E.g., John T. Noonan, JR., NARrowing the NAtion's Power (2002); Robert C. Post \& Reva B. Siegel, Protecting the Constitution from the People, Juricentric Restriction on the Section 5 Power, 78 IND. L.J. 1 (2003) ("In a recent string of decisions invalidating federal civil rights legislation, the Supreme Court has repeated the simple but powerful message: "The Constitution belongs to the courts."').

283. Large firms might well treat ideas the way some firms treat patents - as defensive rather than offensive weapons. Alternatively, privatizing ideas might well result in the pooling of some idea rights, along the lines of the Associated Press model, and vertical integration around others, leading to an aggregate production model similar to the one we have now. Small producers would be bigger losers, however. 
lobbying for such a change, which seems as fanciful as Professor Ely's hypothetical law banning the removal of gall bladders. ${ }^{284}$

More to the point, it is hard to see how the dichotomy would fit into the First Amendment. Much of the action on the idea/expression dichotomy involves instrumental expression that is used in ways at best tangentially related to free speech values. The cases are about ledgers, ${ }^{285}$ contest rules, ${ }^{286}$ insurance forms, ${ }^{287}$ spreadsheet user interfaces, ${ }^{288}$ or taxonomy of dental procedures. ${ }^{289}$ In their most common use, many of these works would not implicate free speech protections, ${ }^{290}$ which means that in at least some cases the dichotomy itself cannot be a First Amendment requirement.

The very idea of privatizing ideas is so amorphous it is hard to see how such a right would be implemented, or how the First Amendment would attack it. At best the notion of copyrighting ideas might produce a speech "bottleneck," analogous to the physical wireline bottleneck in Turner, and thus justify the sort of strict-intermediate scrutiny we examined in Part II. That is still fairly deferential scrutiny, however, and one still faces the problem that the First Amendment does not provide a measure for the "substantiality" of whatever record Congress might build to justify such an unlikely move. ${ }^{291}$ That problem is complicated in this context because the distinction between ideas and expression is not always clear. ${ }^{292}$

As a First Amendment doctrine, fair use is a mess. The Act preserves fair uses by telling courts to balance, on an ad hoc basis, several nonexclusive factors Congress adapted from an 1841 decision. ${ }^{293}$ Even a strong defender

284. John Hart Ely, Democracy and Distrust 182 (1980). As Professor Ely says: "[I]t can only deform our constitutional jurisprudence to tailor it to laws that couldn't be enacted, since constitutional law appropriately exists for those situations where representative government cannot be trusted, not those where we know it can." Id. at 183.

285. Baker v. Selden, 101 U.S. 99 (1879).

286. Morrisey v. Procter \& Gamble Co., 379 F.2d 675 (1st Cir. 1967).

287. Cont'l Cas. Co. v. Beardsley, 253 F.2d 702 (2d Cir. 1958).

288. Lotus Dev. Corp. v. Borland Int'1, Inc., 49 F.3d 807 (1st Cir. 1995), aff'd per curium, 516 U.S. 233 (1996)

289. Am. Dental Ass'n v. Delta Dental Plans Ass’n, 126 F.3d 977 (7th Cir. 1997) (Easterbrook, J.).

290. See McGowan, supra note 19. Professor Yen discusses the idea/expression dichotomy with regard to claims that one software program copies the "look and feel" of another, but does not discuss whether programs are protected speech. Yen, supra note 1, at 398-407. This is in fact a complex question, which has to be resolved before concluding there is a First Amendment problem. See McGowan, supra note 19. Commodities Future Trading Comm'n v. Vartuli, 228 F.3d 94, 110-12 (2d Cir. 2000).

291. See supra notes 106-10.

292. See Rubenfeld, supra note 1, at 14 ("Distinguishing ideas from expression is notoriously tricky.").

293. Folsom v. Marsh, 9 F. Cas. 342, 348 (C.C.D. Mass. 1841 (No. 4, 901)). On balancing, see 
of fair use rights calls the Act "uninformative." ${ }^{" 294}$ More to the point, fair use analysis requires judges to act in ways the First Amendment ordinarily forbids. Fair use "presupposes 'good faith' and fair 'dealing." 295 The First Amendment does not. Fair use requires judges subjectively to evaluate the importance of work copied. The First Amendment warns judges not to consider the "value" of speech. ${ }^{296}$ Economic motives and market effects cut against fair use. ${ }^{297}$ That is not true for the First Amendment. ${ }^{298}$

Fair use is a defense, on which the burden of proof lies with the defendant. ${ }^{299}$ One of the main points of Sullivan, and Speiser $v$. Randall, ${ }^{300}$ on which it was based, is that speakers cannot be required to show the truth or legality of their speech. ${ }^{301}$ Fair use was not even part of the statute until $1976,{ }^{302}$ implying that if this argument is right, the Copyright Act either was in secret violation of the Constitution for most of its life or was inadvertently saved by judges who thought they were following English law. ${ }^{303}$ Congress amended the fair use provision of the Act in 1992 to offset what it worried was an excessively narrow interpretation of fair use, a result copyright critics like but which is at odds with the notion that what is in the statute is itself constitutional. ${ }^{304}$

One could of course look at these facts and say the Court has been wrong to let the fair use doctrine persist in the face of such outrageous deviations from First Amendment doctrine. The deviations could be read as a call for

Campbell v. Acuff-Rose Music, Inc., 510 U.S. 569, 578 (1994).

294. Pierre N. Leval, Fair Use Rescued, 44 UCLA L. Rev. 1449, 1454 (1997). For a collection of similar criticism, see Rubenfeld, supra note 1, at 16-17.

295. Harper \& Row, Publishers Inc. v. Nation Enters., 471 U.S. 539, 562 (1984) (quoting Time, Inc. v. Bernard Geis Assocs., 293 F. Supp. 130, 146 (S.D.N.Y. 1968))

296. See Cohen v. California, 403 U.S. 15, 25 (1971).

297. See Campbell, 510 U.S. at 590.

298. N.Y. Times Co.v. Sullivan, 376 U.S. 254, 266 (1964) ("That the Times was paid for publishing the advertisement is as immaterial in this connection as is the fact that newspapers and books are sold.").

299. Campbell, 510 U.S. at 590.

300. Speiser v. Randall, 357 U.S. 513 (1958).

301. See Sullivan, 376 U.S. at 271.

302. Campbell, 510 U.S. at 576.

303. Leval, supra note 294, at 1451-53 (tracing history of doctrine); Pierre N. Leval, Toward a Fair Use Standard, 103 HARV. L. REV. 1105 (1991) (describing fair use doctrine as developing after enactment of the Statute of Anne and being "received" by American judges). All the cases Justice Story cited on the fair use question in Folsom v. Marsh are from English courts. Folsom v. Marsh, 9 F. Cas. 342, 348 (C.C.D. Mass. 1841) (No. 4, 901). Professor Patterson, however, argues that in Folsom, Justice Story distorted the fair use doctrine to get around the then-prevailing rule that abridgements did not infringe. Patterson, supra note 1 , at 39 .

304. 17 U.S.C. $\$ 107$ (2000) ("The fact that a work is unpublished shall not itself bar a finding of fair use if such finding is made upon consideration of" the fair use factors.). 
reform, not inquiry. ${ }^{305}$ But that reading cannot withstand the Eldred Court's endorsement of the "traditional contours" of copyright. ${ }^{306}$ And the Justices are not fools. They know full well that fair use does not conform to standard First Amendment doctrine. If they thought there were compelling reasons to apply the First Amendment to reform the doctrine they are perfectly capable of saying so. They never have.

The Court's unusual language is best read as an acknowledgment that copyright and the First Amendment often deal with the same subject matter but do so at different levels. Both bodies of law assume authors are economically rational actors, which is why the Court refers to copyright as the "engine of free expression." 307 The Court's constitutional analysis is and has to be much more abstract than Congress's statutory analysis, however.

As I have emphasized throughout this article, to turn basic rational actor assumptions into more finely grained policies one has to gather and analyze a lot of data. How strong incentives are at the margin, how technical change affects them, how the relevant variables net out relative to production as between upstream and downstream authors - these are all notionally empirical questions the Court cannot hope to answer. Congress may have only a vague idea, too, but it is in a much better position than the Court to do these jobs, and the Court knows it.

If the Court tried to hand down concrete limitations on copyright, at best it would produce Miranda-like restrictions that would look and be almost wholly arbitrary. ${ }^{308}$ Upstream producers could assert as many non-falsifiable arguments against them as downstream producers could assert in their defense. It may be possible to invent a rule striking a balance between conflicting interests, such as the conflict between order and liberty, in the case of Miranda, or between speech and reputation, in the case of Sullivan. When the same values are on both sides of the equation, however, as they are in copyright, that sort of invention is much harder.

That means Congress has extremely broad discretion over the length and scope of copyright so long as it takes some steps to show that it recognizes and is keeping an eye on the overlap between copyright and First Amendment values. The language from Harper \& Row and Eldred acknowledges that, in this area of the Constitution, the Court and Congress $d o$ work together, and it is Congress that must take the lead. Congress's treatment is good enough for

305. See Volokh, supra note 1 .

306. Eldred v. Ashcroft, 123 S. Ct. 769, 790 (2003).

307. Harper \& Row, Publishers Inc. v. Nation Enters., 471 U.S. 539, 558 (1984).

308. Miranda v. Arizona, 384 U.S. 436 (1966). 
the Court, and by implication the First Amendment, not because the public choice critique of copyright is wrong, nor because Congress is doing such a bang-up job, but because the Court really has no other choice. Its only alternative would be to start issuing fundamentally arbitrary ukases. With speech interests on both side of these cases, that is not something it is eager to do.

One question remains. As noted in Part IIIA, fair use is inherently an $e x$ post analysis. ${ }^{309}$ Why not extend the point and say copyright should be wholly ex post too, the forward-looking nature of First Amendment doctrine notwithstanding? The argument is quite powerful: From an ex post point of view, everything should be in the public domain. (Conversely, of course, one could ask why New York Times v. Sullivan ${ }^{310}$ and Simon \& Schuster v. New York Crime Victims' Board ${ }^{311}$ do not prevent Congress from adopting ex post analysis in any respect.)

My analysis here suggests that Congress is free to expand the fair use defense, repeal the Copyright Act, or otherwise maximize the extent of the public domain. In this regard, Justice Ginsburg's reference in Eldred to the "traditional contours of copyright protection" being immune from First Amendment scrutiny is important. ${ }^{312}$ The Court understands those contours well enough and, more importantly in light of the analysis in this Part, it can look back over time and see the effects those contours have produced. It seems to like them.

Copyright's historical track record gives the Court some empirical basis for believing that fair use fits well with its general view of the regulation of expression. ${ }^{313}$ History, to some degree, fills the evidentiary gap between the Court and Congress. Technology changes in a hurry, which means historical evidence is not as useful as the kind of evidence Congress can gather, which in turn means the Court will be especially deferential to laws based on the

309. See supra Part IIIA.

310. 376 U.S. 254 (1964).

311. 502 U.S. 105 (1991).

312. Eldred v. Ashcroft, 123 S. Ct. 769, 789 (emphasis added).

313. That is one reason why the Court is more suspicious of regulations it treats as content-neutral when the regulations affect "venerable" means of communication, such as signs on one's home or lawn, than of other such regulations. See City of Ladue v. Gilleo, 512 U.S. 43, 54-55 (1994) ("[R]esidential signs have long been an important and distinct medium of expression.”). My thanks to Dan Farber for drawing my attention to this point. 
theory that technology has changed, which it always does. ${ }^{314}$ Nevertheless, for all these deficiencies, historical evidence is still worth something to the Court.

In the Court's view, fair use has worked pretty well. That does not mean it is itself constitutional, or even coherent. It does not mean users are entitled to the cheapest means of engaging in it. ${ }^{315}$ Justice Ginsburg's comment does suggest, however, that the Court would be concerned if it thought Congress was altering radically a copyright law the justices seem to think has worked pretty well. On this reading, the First Amendment may put up some very broad guardrails on the path copyright has taken, but it cannot choose the course. ${ }^{316}$ By parity of reasoning, the First Amendment does not compel significant changes in copyright law. It cannot be read as a source of radical reform.

\section{CONCLusion}

The copyright crowding-out argument has produced some of the most imaginative and insightful scholarship of the last thirty years. Unfortunately, the argument is fighting a host of problems it cannot defeat. The First Amendment does not resolve conflicts among speakers. When the argument creates more of them, it weakens its own case. At best, the Court will use the First Amendment to keep copyright on roughly the path it has been on for a long time. That is bad news for those who do not like the path. But the First Amendment does not compel Congress to go down that path, either. The case has to be made in Congress. In a democracy, as imperfect as it may be, that's not such a bad thing.

314. E.g., Easterbrook, Law of the Horse, supra note 110, at 208 ("Cyberspace reduces the effective cost of copying. This continues a trend that began when Gutenberg invented movable type and gave rise to political demand for what has become copyright law.").

315. See Universal City Studios, Inc. v. Corley, 273 F.3d 429, 459 (2d Cir. 2001).

316. This is essentially the point of Justice Breyer's concurrence in Turner as well. See Turner Broad. Sys., Inc. v. FCC, 520 U.S. 180, 226-28 (1997) (Breyer, J., concurring). 